\title{
The region of the Strandja Sill (North Turkey) and the Messinian events
}

\author{
Suc Jean-Pierre ${ }^{1,2}{ }^{*}$, Gillet Herve ${ }^{3}$, Cagatay Namik ${ }^{4}$, Popescu Speranta Maria ${ }^{5}$, Lericolais Gilles ${ }^{6}$, \\ Armijo Rolando ${ }^{7}$, Melinte-Dobrinescu Mihaela ${ }^{8}$, Sen Şevket ${ }^{9}$, Clauzon Georges ${ }^{10}$, Sakinc Mehmet ${ }^{4}$, \\ Zabci Cengiz ${ }^{4}$, Ucarkus Gulsen ${ }^{11}$, Meyer Bertrand ${ }^{1,2}$, Cakir Ziyadin ${ }^{4}$, Karakas Çağil ${ }^{7}$, \\ Jouannic Gwenael ${ }^{12}$, Macalet Rodica ${ }^{13}$
}

${ }^{1}$ Sorbonne Universités, UPMC Univ. Paris 06, UMR 7193, Institut des Sciences de la Terre Paris (iSTeP), 75005 Paris, France

${ }^{2}$ CNRS, UMR 7193, Institut des Sciences de la Terre Paris (iSTeP), 75005 Paris, France

${ }^{3}$ EPOC, Université Bordeaux 1, 33405 Talence, France

${ }^{4}$ Istanbul Technical University, Faculty of Mines, Department of Geological Engineering, 34469 Ayazağa Istanbul, Turkey

${ }^{5}$ GeoBioStratData.Consulting, 385 route du Mas Rillier, 69140 Rillieux la Pape, France

${ }^{6}$ Ifremer, 92138 Issy les Moulineaux, France

${ }^{7}$ Tectonique et Mécanique de la Lithosphère, Institut de Physique du Globe de Paris, UMR 7154 CNRS, 75238 Paris Cedex 05 France

${ }^{8}$ National Institute of Marine Geology and Geo-ecology, 23-25 Dimitrie Onciul street, P.O. Box 34-51, 70318 Bucharest, Romania

${ }^{9}$ Centre de Recherche sur la Paléobiodiversité et les Paléoenvironnements, UMR 7207 CNRS, Muséum National d'Histoire Naturelle, Paris, France

$1{ }^{0}$ Aix-Marseille Université, CNRS, IRD, CEREGE UM34, 13545, Aix-en-Provence, France

$1^{1}$ İstanbul Technical University, Eurasia Institute of Earth Sciences, 34469 Ayazağa İstanbul, Turkey

$1{ }^{2}$ Cerema, DTer Est, Laboratoire Régional des Ponts et Chaussées de Nancy, 54510 Tomblaine, France

$1{ }^{3}$ National Institute of Hydrology and Water Management, 97 Bucuresti-Ploiesti Road, 013686 Bucharest, Romania

*Corresponding author : Jean-Pierre Suc, email address : jeanpierre.suc@gmail.com

\begin{abstract}
:
The two sides of the Strandja Sill show a highly discontinuous stratigraphic succession since the Late Oligocene. This area, together with the Sea of Marmara Basin, is usually proposed as the gateway for the Paratethyan freshwaters and organisms that constituted the Lago Mare facies in the Mediterranean Sea during the Messinian Salinity Crisis (MSC). Our investigations involving new field observations and datings, together with previous studies, suggest that the sill has possibly experienced such a connection at around $8 \mathrm{Ma}$, i.e. significantly before the crisis. The proposal of a sea-level drop of the Black Sea before $7 \mathrm{Ma}$ is not supported by our data on dinoflagellate cysts. Consistency of calcareous nannofossil succession at DSDP Site 380 is reinforced, allowing to reassert that subaerial erosion impacted both the southwestern Black Sea and the central Marmara - Dardanelles area during the peak of the MSC. At that time, this region was crossed by two oppositely directed fluvial networks, further supporting the
\end{abstract}


absence of a marine gateway through the Strandja Sill. It is concluded that none of the Lago Mare events recorded in the Mediterranean during the MSC were the consequence of the passage of Paratethyan waters and organisms through this area. In the Black Sea, the well-dated Messinian fluvial erosion can be followed offshore. The overlying prograding deltaic deposits attest to a fast marine reflooding after the crisis. This constitutes a comprehensive erosion - sedimentation model in an area intensively explored for hydrocarbons.

\section{Highlights}

- Two opposite fluvial networks crossed the Thrace Basin between 6 and $5 \mathrm{Ma}$. Evidence of subaerial erosion in the Black Sea at that time is reinforced. Paratethys-Mediterranean did not connect over the Strandja Sill at that time. A Balkans corridor was used by Paratethyan organisms for the Lago Mare facies.

Keywords : Mediterranean-Paratethys connection, Onshore-offshore stratigraphy, Messinian Salinity Crisis, Erosion, Fluvial network

\section{Introduction}

The region of the Strandja Sill is a relatively low land area, located to the west of the Bosphorus Strait, which today constitutes the water divide between the Marmara Sea and the Black Sea (Fig. 1). Along the profile $a-b$ (Figs. 1, 2), its altitude varies between 100 and $200 \mathrm{~m}$, except for some depressions often occupied by lakes and lagoons, with the highest points on the Marmara side (Fig. 2). The region is crossed by the presently inactive N-S trending West Black Sea Fault (Fig. 1B; Okay et al., 1994), and bordered to the West by the Thrace-Eskişehir Fault Zone inactive since the Pliocene (Perincek, 1991), and to the South by the North Anatolian Fault in the Sea of Marmara (Armijo et al., 1999, 2002; Yaltırak et al., 2000; Imren et al., 2001; Le Pichon et al., 2001; Şengör et al., 2005, 2014). Because of its morphology and topography, the region has long been usually considered as a gateway that is supposed to have been periodically connecting the Black and Aegean seas, i.e. the Eastern Paratethys and the Mediterranean (Fig. 1A; Rögl and Steininger, 1983; Cağatay et al., 2006; Popov et al., 2006) before its uplift that palaeogeographic reconstructions attributed to a compressional tectonics (Sakınç et al., 1999; Sakınç and Yaltırak, 2005). Such a connection is generally considered to have allowed the invasion of Paratethyan organisms into the 
Mediterranean at the time of the Messinian Salinity Crisis (MSC), recorded within the Lago Mare facies (Orszag-Sperber, 2006; Krijgsman et al., 2010).

The interest for this region increased since the evidence of a well-marked erosional surface in the southwestern Black Sea from DSDP Site 381 to Site 380 (Hsü and Giovanolli, 19791980) has been referred as the Messinian Erosional Surface (MES) by Gillet et al. (2007). This ascription was supported by the palynological study of Popescu (2006) and recently robustly confirmed by a detailed and complete climatostratigraphic record and, especially, a succession of consistent calcareous nannofossil assemblages (Popescu et al., 2010).

Following some successes, hydrocarbon exploration is revitalized in the Black Sea with the possibility of an unconformity (MES) type trap and clastic reservoirs at base of the Pliocene (Tari et al., 2009, 2013; Georgiev, 2012; Sacleux et al., 2013; Nikishin \& Petrov, 2014).

On the basis of the present-day available information, this work aims to specify if the Strandja Sill may have been a marine gateway at the time of the MSC by (1) providing new datings on the related sedimentary sequences onshore, (2) presenting new onshore data on the Black Sea side (Fig. 1B), and (3) providing unpublished offshore seismic profiles in the SW Black Sea (Fig. 1B).

\section{Methods.}

Field investigation was the main tool used in this work. It involved mostly calcareous nannofossil analyses, which were performed using a light polarizing microscope at x1600 magnification. Taxonomic identification followed Perch-Nielsen (1985) and Young (1998). Some pollen grain and dinoflagellate cyst analyses have been made after a classical treatment 
of clayey samples: $\mathrm{HCl}$ and $\mathrm{HF}$ acid digestions followed by a separation within $\mathrm{ZnCl}_{2}$ at density 2 and finally sieving at $10 \mu \mathrm{m}$.

Three high-resolution multichannel seismic profiles acquired during the Ifremer's BlaSON2 survey (August-September, 2002) by the R/V "Le Suroît" were used. Age assignments to the seismic stratigraphic units were made using correlations with the welldated units in the offshore petroleum exploration boreholes Gillet et al., 2007). Because the in situ measured velocities were not available for these boreholes, we based their depth to time conversion on the BlaSON 2 seismic data stack velocities (see: Gillet et al., 2007).

\section{Geological setting of the Strandja Sill and new biostratigraphic data on the youngest} sediments

The Strandja Sill, as observable along the simplified section $\mathrm{a}-\mathrm{b}$ from Figure 1, displays a stratigraphic succession starting with the Lower Carboniferous Trakya Formation (siliceous shales, sandstones, limestones, conglomerates) of the İstanbul Zone (Okay et al., 1994 Okay and Tüysüz, 1999) unconformably overlain by the Middle-Upper Eocene sediments of the Thrace Basin (sandstones, marls, limestones) (Figs. 1B, 2; Yurtsever and Çağlayan, 2002; Less et al., 2011). The youngest sediments, from Oligocene to Upper Miocene, are unconformably distributed both on the Marmara Sea and Black Sea sides of this succession (Figs. 1, 2; Okay and Özcan, 2014).

\subsection{Age of the Oligocene and Miocene units}

On the Marmara Sea side of the transect, the Danişment Formation made of cross-bedded diversified gravels and pebbles in a reddish matrix is ascribed to the Late Oligocene (Duman 
et al., 2004). The overlying Neogene Çukurçeşme Formation mostly consists of sands and gravels which, at Küçükçekmece (Fig. 1B), provided a mammal fauna, the main elements of which are Deinotherium giganteum, Choerolophodon pentelici, Paramachairodus orientalis, Felis cf. attica, Percrocuta senyureki, Ictitherium sp., Indarctos arctoides, Lutra sp., Amphiorycteropus gaudryi, Hipparion sp., Chilotherium habereri, Ceratotherium neumayri, Microstonyx erymanthius, Dorchatherium puyhauberti, Bohlinia attica, Orasious speciosus, Gazella gaudryi, Helicotragus rotundicornis, Palaeoreas lindermayeri and Tragoportax amalthea (Malik \& Nafız, 1933). Above it, the Bakırköy Formation, consisting of limestone interbedded with claystone at the base, is ascribed to the Mid-Upper Miocene on the basis of its Mactra-rich mollusc fauna rich that is assigned to the Paratethyan Sarmatian s.l. Stage (Chaput and Gillet, 1938; Gillet et al., 1978). This age has been confirmed on the basis of micropalaeontological analyses by Şafak et al. (1999).

\subsection{New data on the Oligocene and Miocene units}

Since 2005, we have performed several field investigations on both sides of the Strandja Sill, with the aim to obtain new age data from the Oligocene and Miocene sections. The results are described below, first for the Sea of Marmara side of the sill, and then for the Black Sea side.

\subsubsection{Sea of Marmara side}

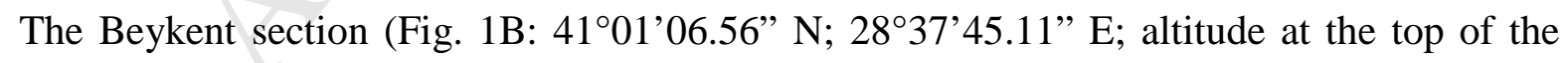
section: $198 \mathrm{~m}$ ), due to a recent excavation for buildings, displays the complete Late Paleogene - Neogene sedimentary successions of the Marmara side of the Strandja Sill (Fig. 2). The 24 m-thick section, from bottom to top, consists of (Figs. 3A, B): 
- 12 m thick, cross-bedded polygenic conglomerate (Upper Oligocene Danişment Formation) (Fig. 3C) with a reddish matrix and some clayey lenses (Fig. 3D);

- $\quad 3$ m thick grey sands (Fig. 3E) with an erosional base (Mid-Upper Miocene Çukurçeşme Formation);

- $9 \mathrm{~m}$ thick alternating dark to light tabular clays and limestones (Fig. 3E) with silty to sandy layers (Mid-Upper Miocene Bakırköy Formation) which conformably overlays the Çukurçeşme formations.

The Hipparion fauna from Küçükçekmece (Fig. 1B; Malik \& Nafiz, 1933), which dates the Çukurçeşme Formation, has been revised (Sen, in preparation: see above for the faunal list). Its estimated age is latest Mammalian Neogene MN10 Zone, i.e. ranging between 9 and 8.7 Ma. The six samples taken within the Bakırköy Formation for search of calcareous nannofossils were barren.

The Bakırköy Formation can also be observed in the cliffs bordering the Sea of Marmara shoreline at Avc1lar (Fig. 1B: 4058'19.34” N; 2844’07.05” E; altitude: $17 \mathrm{~m}$ ). It shows almost the same lithological succession as at Beykent with a greater abundance of limestone at its top (Fig. 4). Six samples have been taken for searching calcareous nannofossils (Fig. 4): samples 3, 4 and 5 were barren. Samples 1, 2 and 6 provided poor nannofloras, with low diversity (number of species) and abundance (number of recorded specimens), composed of Sphenolithus abies, Coccolithus pelagicus, Reticulofenestra pseudoumbilicus, small reticulofenestrids, and the calcareous dinoflagellate Thoracosphaera spp. Reworked nannofossils of Cretaceous, Eocene and Oligocene are frequent. The only biostratigraphic marker species of this assemblage, $R$. pesudoumbilicus, has a range from the late Early Miocene to late Zanclean, and Sphenolithus abies from the late Mid-Miocene to $3.7 \mathrm{Ma}$ (Martini \& Müller, 1986; Raffi et al., 2006). We found some molluscs from the base of the sands overlying sample 4 (Fig. 4) with Hydrobia sp., Cardium sp. and Pirenella sp. which 
indicate a Sarmatian s.l. age with respect to the Paratethyan Stratigraphy, in agreement with the late Sarmatian s.l. age proposed by Gillet et al. (1978), on the basis of a richer malacofauna from the same beds. According to Vasiliev et al. (2011), the top of the Upper Sarmatian s.l. (= Kersonian) is located at about $8 \mathrm{Ma}$.

Because of the absence of any unconformity between the Bakırköy and Çukurçeşme formations, and according to the age indicated by the Küçük Çekmece mammal fauna ( $9-8.7$ Ma) and the late Sarmatian s.l. age of the Mactra fauna, we consider an age close to 8 Ma for the top of the Bakırköy Formation, which is consistent with the occurrence of the nannofossil Reticulofenestra pseudoumbilicus.

At Kayabaşı (Fig. 1B: 4106'13.57” N; 2846’37.26” E; altitude: 115 m), a thin clayey layer within carbonates unconformably topping the Eocene deposits provided a poor nannoflora with Coccolithus pelagicus, Reticulofenestra minuta, R. haqii and Sphenolithus abies, covering the Mid-Miocene to the Early Pliocene interval (Martini \& Müller, 1986; Raffi et al., 2006).

\subsubsection{Black Sea side}

The Akpinar quarry (Fig. 1B: $41^{\circ} 16^{\prime} 46.64^{\prime \prime} \mathrm{N} ; 2^{\circ} 49^{\prime} 04.77^{\prime \prime} \mathrm{E}$; altitude at the base of the quarry: $55 \mathrm{~m}$ ) displays an impressive $37 \mathrm{~m}$-thick lignite-clay succession overlain by sandygravelly-clayey deposits (Figs. 2, 5A). According to the geological map, the lower part belongs to the Danişment Formation ascribed of Late Oligocene age and the upper part to the Belgrad Formation of Middle-Late Miocene age (Yurtsever and Çağlayan, 2002). A stratigraphic gap probably separates the two parts of this succession. Teeth of a lagomorph (Albertona sp., primitive form) and a rodent (Eucricetodon sp.) were recorded from the muck of the excavation. The first one is known in Early Miocene localities in Greece and Turkey (Ünay et al., 2001). However, the described species have a more evolved dentition than that of 
the Akpinar quarry. Eucriceton is a common genus in Oligocene and Early Miocene of Eurasia (Hugeney, 1999). These mammals can be considered for dating the lower part of the quarry. Some samples have been analysed for calcareous nannoplankton and palynology (Fig. 5B, 5C). Only sample 4 contains nannofloral assemblage with, among others, the following biostratigraphic markers: Calcidiscus macintyrei, Cyclicargolithus floridanus, Sphenolithus abies and Reticulofenestra pseudoumbilicus. C. floridanus disappeared in the late MidMiocene (Martini \& Müller, 1986), at ca. 12 Ma (Raffi et al., 2006), and C. macintyrei appeared in the Mid-Miocene (Martini \& Müller, 1986), at ca. 12.4 Ma (Raffi et al., 2006). An age of $c a .12 \mathrm{Ma}$ (late Middle Miocene), consistent with the occurrence of $R$. pseudoumbilicus and S. abies (see above; Martini \& Müller, 1986), may be considered for the uppermost clays of this succession. This lacustrine succession probably discontinuously range in age from the Late Oligocene to Early and Middle Miocene. This is consistent with the pollen content of samples 1, 2 and 3 (Figs. 5B, 5C) which indicates freshwater swampy to riparian conditions with predominance of Taxodium-type, Alnus, Engelhardia, Myrica, Zelkova, Carya, etc. Such a pollen assemblage is already known from Oligocene of the Thrace Basin (İslamoğlu et al., 2010). Sample 3 (Fig. 5C) is also characterized by abundant spores of Pteridophyta, which indicates some fluvial input.

The upper part of the Miocene succession can be observed at Kocayemiş (Fig. 1:

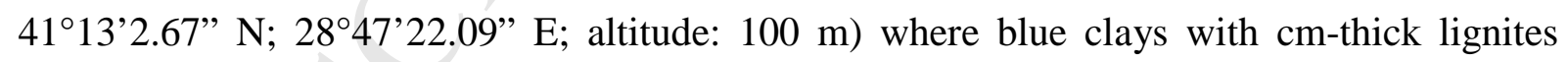
alternate with channeled reddish sands and gravels in $25 \mathrm{~m}$-thick section. Four samples from these clays did not provide any calcareous nannofossil.

To the West, in the area of Karacaköy (Fig. 1B), important differences in sedimentation and geomorphology characterize the two sides of the Strandja Ranges, made of the old basement rocks (granites, schists, quartzites, etc.; Çağlayan \& Yurtsever, 1998), through the Karamandere pass. The sediments on both sides of the pass are usually ascribed to the Ergene 
Formation (Sakinç et al., 1999), which is Upper Miocene in age according to Çağlayan \& Yurtsever (1998). In the West Thrace Basin, the Upper Miocene age of the sediments is attested by the Late Vallesian mammal fauna of Yulafli (Kaya \& Heissig, 2001; Geraads et al., 2005). However, the sediments filling the triangular area of Karacaköy northward of the Karamandere pass are not dated, but were previously ascribed to Pliocene (Ternek, 1964), a concept which at that time also encompassed the latest Miocene. Southward of the pass, the surface sediments (locality 1 in Figure 6A) are constituted by reddish alluvial loams and gravels affected by pedogenetic alteration. They are cut by quartz veins (Fig. 6B). Such deposits correspond to an alluvial plain with lens-shaped channel intercalations, also attested by the almost flat surface morphology at an altitude between 170 and $200 \mathrm{~m}$ (Fig. 6A). On the northern edge of the Karamandere pass, the sediments are composed of almost horizontal yellowish to whitish cross-bedded sands and gravels (Figs. 6C - E) while the altitude of their top progressively decreases from $115 \mathrm{~m}$ at locality 2 to $81 \mathrm{~m}$ at locality 4 (Fig. 6A). Such sediments are typical of fluvial-deltaic deposition that is also supported by their triangular geometry (Fig. 6A) their content of abundant transported tree trunks (Fig. 6F). At the Karamandere pass and immediately northward (Fig. 7A), these fluvial-deltaic sediments are obviously nested within the basement of the Strandja Ranges (Fig. 7B), from which we consider that they are separated by an erosional surface (Figs. 6A and 7B).

\subsubsection{Deep Black Sea}

Popescu (2006: her figure 3) documented several layers with dinoflagellate cysts below the Pebbly Breccia Unit which, at DSDP Site 380, has been considered to mark the Messinian Salinity (Hsü and Giovanoli, 1979-1980), between 883.50 and $864.50 \mathrm{~m}^{1}$. As a support to this ascription, the earliest Zanclean is indicated by two marker species, Ceratolithus acutus and

\footnotetext{
${ }^{1}$ Depths are expressed in metres below sea floor.
} 
Triquetrorhabdulus rugosus (Raffi et al., 2006) at $840.07 \mathrm{~m}$, i.e. $24.43 \mathrm{~m}$ above the Pebbly Breccia (Fig. 8; Popescu et al., 2010).

Eleven samples have been re-examined for the dinoflagellate content at $1019.85 \mathrm{~m}, 1018.85$ m, $1017.82 \mathrm{~m}, 1010.53 \mathrm{~m}, 1009.36 \mathrm{~m}, 1008.68 \mathrm{~m}, 976.99 \mathrm{~m}, 849.10 \mathrm{~m}, 846.16 \mathrm{~m}, 841.91 \mathrm{~m}$, and $840.07 \mathrm{~m}$.

They provided (Fig. 8):

- Paratethyan species: Spiniferites balcanicus (841.91 m, 840.07 m) (Pl. 1, Figs. 6a-6b), Romanodinium areolatum (1009.36 m, 840.07 m) (Pl. 1, Figs. 4a-4b), Galeacysta etrusca $(1009.36 \mathrm{~m}, 1008.68 \mathrm{~m}, 846.16 \mathrm{~m}, 840.07 \mathrm{~m})\left(\mathrm{Pl} .1\right.$, Figs. 2a-2b) ${ }^{2}$, Caspidinium rugosum (1008.68 m, 849.10 m, 846.16 m, 841.91 m), Spiniferites cruciformis (1008.68 m, 846.16 m, 841.91 m, 840.07 m), Impagidinium caspienense (1009.36 m, 1008.68 m), I. globosum $(840.07 \mathrm{~m})$, Millioudodinium punctatum $(840.07 \mathrm{~m})$, Spiniferites bentorii pannonicus (1008.68 m, $976.99 \mathrm{~m})$, S. bentorii granulatus $(1018.85 \mathrm{~m}, 1017.82 \mathrm{~m}$, 976.99 m), S. maisensis (976.99 m, 840.07 m), S. tihanyensis $(1019.85$ m, $1017.82 \mathrm{~m}$, $976.99 \mathrm{~m}, 840.07 \mathrm{~m})$, and $S$. validus $(1019.85 \mathrm{~m}, 1017.82 \mathrm{~m}, 1008.68 \mathrm{~m}, 976.99 \mathrm{~m})$;

- and marine species: Achomosphaera andalusiensis (1019.85 m, 1008.68 m, 976.99 m, 840.07 m), Hystricokolpoma spp. (976.99 m, 840.07 m), Impagidinium patulum (976.99 m, 840.07 m), I. sphaericum $(840.07$ m), I. aculeatum (840.07 m), Impagidinium spp. (1009.36 m, 1008.68 m, 976.99 m, 840.07 m), Lingulodinium machaerophorum (1019.85 m, 1008.68 m, 976.99 m), Operculodinium centrocarpum (976.99 m, 840.07 m), Polysphaeridium zoharii (976.99 m, 840.07 m), Spiniferites mirabilis (1008.68 m, 976.99 m), S. membranaceous (976.99 m), S. bentorii (1008.68 m, 976.99 m, 840.07 m), S. hyperacanthus (1010.53 m, 976.99 m), S. bulloideus (1019.85 m, 1010.53 m, 1009.36

\footnotetext{
${ }^{2}$ Because of close morphologies, Spiniferites balcanicus Baltes 1971, Romanodinium areolatum Baltes 1971 and Galeacysta etrusca Corradini and Biffi 1988 have been grouped in the Galeacysta etrusca Complex (Popescu et al., 2009).
} 
m, $976.99 \mathrm{~m})$, S. ramosus $(1018.85 \mathrm{~m}, 1009.36 \mathrm{~m}, 1008.68 \mathrm{~m}, 976.99 \mathrm{~m}, 840.07 \mathrm{~m})$,

Selenopemphix nephroides (1009.36 m, 976.99 m), Brigantedinium spp. (840.07 m).

This study documents the occurrence of Galeacysta etrusca from $1009.36 \mathrm{~m}$ with other typical Paratethyan dinoflagellate cysts recorded from $1019.85 \mathrm{~m}$. The presence of Spiniferites validus between 976.99 and $1019.85 \mathrm{~m}$ allows to ascribe an age of ca. 9.2 to 8.1 Ma (late Tortonian) to this interval (S. validus Zone: Magyar et al., 1999a, 1999b). These samples also document inflows of marine waters into the Black Sea before and after the Messinian Crisis, probably from the Mediterranean Sea. The sample at $840.07 \mathrm{~m}$ marks the beginning of a long sequence of Mediterranean water inflow, at least up to $704.34 \mathrm{~m}$ as documented by Popescu (2006).

\section{Messinian erosion in the Black Sea}

\subsection{Southwestern Black Sea}

The BlaSON1 and 2 surveys (Ifremer: 1998 and 2002, respectively) have tracked an erosional surface in several seismic profiles the erosional surface (Gillet et al., 2003, 2007), which was previously detected by Letouzey et al. (1978), particularly between DSDP Sites 381 and 380 (Fig. 1B). This erosional surface was attributed to a significant sea-level fall in the Black Sea as a consequence of the Messinian Salinity Crisis in the Mediterranean (Gillet et al., 2007), marked at Site 380 by the above mentioned Pebbly Breccia composed of dolomitic clasts and stromatolitic dolomite blocks (Hsü and Giovanoli, 1979-1980). This interpretation was supported by the stratigraphic subdivision of several petroleum exploration wells (Gillet et al., 2007), such as İğneada 1 and Karadeniz 1 located in our study area (Fig. 1B). At last, an age of $5.45 \mathrm{Ma}$ has been assigned at Site 380 to the lowermost Aragonitic 
mud Unit (at $861.65 \mathrm{~m}$ bsf) which immediately overlies the Pebbly Breccia (Fig. 8), on the basis of a reliable succession of calcareous nannofossils and a robust climatostratigraphy from pollen data in narrow relationship with well-dated Mediterranean and European pollen records (Popescu et al., 2010). Previous studies interpreted the sea-level fall in the Black Sea as a climatic consequence of the severe sea-level drop of the Mediterranean (Popescu, 2006; Vasiliev et al., 2013). This assertion is supported by a palaeoclimatic numerical modeling suggesting that the climate of the Black Sea became warmer and somewhat drier during the peak of the MSC in the Mediterranean (Bartol and Govers, 2009; Murphy et al., 2009), as shown in a scenario combining a Mediterranean Sea-level drop of $1500 \mathrm{~m}$, with some water remaining in the basin. This scenario was accepted by Bache et al. (2012). Conversely, Tari et al. (this volume) interpreted a new seismic dataset and concluded to a significantly less important sea-level drop. It is to be noted that seismic profiles on the Marmara side of the Strandja Sill (i.e. in the Sea of Marmara) do not record such an erosional surface because of the overprint by the pull-apart basins there post-date MSC and post-MSC-reflooding (Karakaş, 2012).

\subsection{New seismic lines in the Southwestern Black Sea}

The seismic profile BlaSON2-054 is the nearest from the seashore (Fig. 1B). It shows a deep palaeo-valley almost perpendicular to the coastline, up to $800 \mathrm{~ms}$ TWT depth and $900 \mathrm{~m}$ in width in its axial part and $2100 \mathrm{~m}$ at its largest opening on top. This palaeo-valley is filled by sediments which pinch out on its flanks (Fig. 9). Secant to this profile, the line BlaSON2-052 is almost parallel to the shoreline (Fig. 1B). It also shows a deep palaeo-valley almost perpendicular to the coastline, up to $900 \mathrm{~ms}$ TWT depth and $1550 \mathrm{~m}$ in width in its axial part and $3800 \mathrm{~m}$ at its largest opening on top, with the same characteristics of the sediment infil. On the northwestern edge of the palaeo-valley, this line practically crosses the Karadeniz 1 
well (Figs. 1B, 10A) which provides a stratigraphic calibration to seismic reflectors (Fig. 10B) as specified by Gillet et al. (2007) in their figures 9 and 11. The continuity of the erosional truncation allows one to establish that the sediments filling the palaeo-valley are Pliocene in age. The chronostratigraphic ascription of these sediments can hence be extended to those within the palaeo-valley shown by profile BlaSON2-054 (Fig. 10). The same erosional surface may also be observed in line BlaSON 2-051 (Fig. 1B), not in a cross-section view but in a somewhat oblique section (Fig. 11), being followed up to Site 381 as shown by Gillet et al. (2007) in their figure 8. There, sediments overlying the erosional surface are allocated to Pliocene as evidenced by the İğneada 1 well projected on the profile (Fig. 11; Gillet et al., 2007: their figs. 9 and 10). To follow up the erosional surface up to Site 381 and, from it to Site 380 (Fig. 1B) where its overlying sediments are precisely dated (Popescu et al., 2010), allows to consider that this surface is the Messinian Erosional Surface (MES), as proposed by Gillet et al. (2007). This is in agreement with the gap of Upper Miocene deposits in both the Karadeniz 1 and İğneada 1 wells (Gillet et al., 2007). In addition, the longitudinal view of this line shows a prograding sediment package overlying the MES before successive erosions belonging to Quaternary (Fig. 11). Pliocene sediments were deposited in subaqueous conditions and their progradation was probably a consequence of a fast sea-level rise after the above-mentioned sea-level fall. Such sediments may have been supplied by river transport and/or redeposited along the coastline.

\section{Discussion}

This work is the first to investigate the region of the Strandja Sill in relation to the possible impact of the MSC. It provides the opportunity to confirm the robustness of the Messinian 
erosion in the Black sea. Several aspects are now to be interpreted after being discussed in the light of previous studies, other hypotheses and the new information available on this area.

\subsection{Robustness of the Messinian erosion in the Black Sea}

In a recent paper, Grothe et al. (2014) questioned the Messinian age of the erosional surface in the Black Sea on the basis of a study of dinoflagellate cysts from Site 380. They concluded that the sea-level fall recorded in the Black Sea marked by the Pebbly Breccia has an older age at ca. $7 \mathrm{Ma}$. Such an assumption results from the proclaimed first appearance of Caspidinium rugosum and Galeacysta etrusca at the base of the Aragonite Unit $(850.30 \mathrm{~m})$ despite documented information on the underlying layers for supporting a first appearance datum. This interpretation is inaccurate with regard to our records reported above which establish the occurrence of Caspidinium rugosum and Galeacysta etrusca from $1009.36 \mathrm{~m}$ (Fig. 8).

Hence, the Grothe et al. (2014)'s hypothesis cannot be accepted and the late Messinian age of the Pebbly Breccia is still the preferred interpretation. Reliability of the calcareous nannofossils markers Triquetrorhabdulus rugosus and Ceratolithus acutus, fastly discarded by Grothe et al. (2014), can be re-asserted.

The significance of the Pebbly Breccia (originally called "Pebbly mudstone breccia"; Ross et al., 1978) is still debated. For these authors, it might have been deposited in subaqueous conditions in relation with the rapid Black Sea-level rise by marine influx. Conversely, Hsü and Giovanoli (1979-1980) assigned it to debris flows during the time of Black Sea shallowwater. However, Gillet et al. (2007), who evidenced the subaerial erosional surface referred to the MES and tentatively correlated it with the top of the Pebbly Breccia, considered that erosion did not reach the deepest parts of the Black Sea. At the light of new seismic data, Tari et al. (this volume) consider the Pebbly breccia as a mass transport complex. Their proposal 
that the Black Sea experienced a Messinian sea-level drop significantly less than the 1,600 m suggested by Hsü and Giovanoli (1979-1980) is not in contradiction with our observations.

Our dinoflagellate cyst record at DSDP Site 380 shows that the interval $969-841 \mathrm{~m}$ (encompassing the Laminated carbonates, Pebbly Breccia, Aragonite and base of the Lower chalk) is sandwiched between two Mediterranean marine influxes (Fig. 8), probably documenting a higher level of the Black Sea. This interval should thus correspond to a relative lower Black Sea level as supported by higher percentages in halophytes (plants living on the shoreline: mostly Amaranthaceae-Chenopodiaceae, Caryophyllaceae, and Plumbaginaceae) within the pollen assemblage recorded at Site 380, particularly between 940 and $845 \mathrm{~m}$ (Popescu, 2006: her figure 3). Erosional events have occurred prior to the MSC (Gillet et al., 2003; Tari et al., this volume). However, drier climatic conditions correspond to the interval $922-845 \mathrm{~m}$, as pointed out by prevalent Asteraceae with respect to Poaceae among the herbaceous pollen content (Popescu, 2006: her figure 3). This evolution seems consistent with that simulated by Bartol and Govers (2009) and Murphy et al. (2009) supporting an impact of the Mediterranean desiccation on the Black Sea climate. However, it is not excluded that the palaeo-valley shown in seismic profiles BlaSON2-052 and BlaSON2054 began to be cut prior to the MSC and significantly deepened during its peak.

\subsection{A marine gateway at the Strandja Sill?}

The youngest marine influence on the Black Sea side has been dated close to $12 \mathrm{Ma}$ at Akpınar, i.e. in the late Serravallian (early Sarmatian s.l. in the Paratethyan chronostratigraphic scale: Fig. 12; Vasiliev et al., 2011). At that time, the connection between the Eastern Paratethys and the Indian Ocean was closed according to Rögl (1999), who considers a connection with the Mediterranean through a corridor located in northern Syria. There was no simultaneous connection between the Black and Aegean seas which, according 
to Rögl (1999), was established in the area of İstanbul later, during the Tortonian (late Sarmatian s.l. and early Meotian in the Paratethyan chronostratigraphic scale: Fig. 12; Vasiliev et al., 2011). But, such a gateway remains undocumented. The conformity of the Bakırköy Formation above the Çukurçeşme Formation and our calcareous nannofossil evidence on the southern side of the Strandja Sill support some influx of Mediterranean waters, as recorded at Avcılar and Kayabaşı. However, the available information does not support their passage to the northern side of the sill (Fig. 12), except for the late Tortonian occurrences of marine dinoflagellate cysts (Popescu, 2006) and marine diatoms (Schrader, 1978) in the Black shales at DSDP Site 380 as detailed above (Fig. 8). The Mediterranean marine influx evidenced in the area of the Dardanelles Strait (Melinte-Dobrinescu et al., 2009) prior to the MSC concerns the early Messinian according to the co-occurrence of the calcareous nannofossils Reticulofenestra rotaria that firstly appears within the Tortonian/Messinian boundary interval (Raffi et al., 2003), and Nicklithus amplificus that has its first occurrence at 6.84 Ma in the eastern Mediterranean (Raffi et al., 2006). Neither $R$. fenestra nor $N$. amplificus has been recorded at Avcılar and Kayabaşı, indicating that this early Messinian marine influx did not reach the region of İstanbul. Accordingly, the data suggest that no more connection may have existed in this area between the Mediterranean and Paratethys since ca. $8 \mathrm{Ma}$, and particularly when the marine reflooding of the Mediterranean occurred at 5.46 Ma (Bache et al., 2012). This is in agreement with the delayed arrival (at $5.31 \mathrm{Ma}$ ) of the Mediterranean micro-organisms (calcareous nannofossils, dinoflagellates, diatoms) in the southwestern Black Sea (Site 380) with respect to the marine reflooding of the Mediterranean at 5.46 Ma (Popescu et al., 2010; Bache et al., 2012). One must thus consider another gateway for the incursion of Mediterranean waters into the Eastern Paratethys and for the reverse outflow from Paratethys into the Mediterranean. The suitable candidate is the 
Balkans corridor evidenced by Clauzon et al. (2005), Popescu et al. (2009), Suc et al. (2011, and this volume) and Bache et al. (2012).

\subsection{The palaeo-fluvial network}

The fluvial erosion evidenced southward of Karacaköy and the overlying deltaic sediments continuing offshore in a prograding system within the Messinian valley morphology lead us to reject the suggestion of a marine gateway in this area (cf. Krijgsman et al., 2010). In fact, the Karamandere palaeo-gorge was cut by a powerful river as a result of the drop of the Black Sea level, which is particularly evident in the offshore domain. Then, after the sea-level rise at about 5.45 Ma according to the Popescu et al. (2010)'s chronology, the Karamandere palaeogorge became the outlet of this river with its delta on the shoreline. The Karamandere river provided a large quantity of pebbles, gravels and sands which were deposited in the subaqueous foreset beds (seismic line BlaSON2-051: Fig. 11) and then in the subaerial topset beds observed in the Karacaköy area. During the low sea level, this river and several others from the southwestern Black Sea should have transported large amount of coarse clastics to the deepest parts of the basin. These coarse clastics linked to the Messinian events can be potential reservoirs for hydrocarbon accumulation. Palaeo-valleys have also been observed in a $150 \mathrm{~km}$-long seismic profile, extending parallel to the coastline from offshore Varna to the Borphorus Strait, that Nikishin and Petrov (2014) attributed to the Messinian Crisis. Concerning the Messinian fluvial network in the area, the shift from a transverse cross-section of the Messinian valley and its sedimentary filling to a longitudinal one between the lines BlaSON-052 and BlaSON-051 can be explained by two catching different fluvial inputs. One input was probably from the Karacaköy delta as shown by profiles BlaSON-054 and BlaSON052. The BlaSON-051 line, however, indicates yet another stronger river input probably originating from the İğneada Gulf to the North. Further field investigations are thus necessary 
in this area where Pliocene sediments are mapped (Fig. 1B; Ternek, 1964; Yurtsever and Çağlayan, 2002).

A fluvial network flowing from the eastern part of the present-day Marmara Sea area was evidenced during the peak of the MSC (Fig. 13B; Suc et al., 2009), which enter into the northern Aegean basin through the area of the Dardanelles Strait (Melinte-Dobrinescu et al., 2009). The major element of this fluvial system could have been the palaeo-Sakarya River originating from the Central Anatolian Plateau (Fig. 13A). The river, which flowed towards the lowered Black Sea through the Karamandere palaeo-gorge, had an opposite course (Fig. 13B; Suc et al., 2009). Today, a small brook, tributary of the Belgrat River, flows from the Karamandere pass Fig. 6A). This short stream could not have cut the deep Messinian valley observed offshore. Its source is very close to a tributary of the Ergene River, which flows in an opposite course, being itself a tributary of the $480 \mathrm{~km}$ long Maritsa River (Fig. 13A). Melinte-Dobrinescu et al. (2009) described at Enez a very weak Messinian fluvial cutting and a thin post-reflooding sedimentary filling, indicating that only a small river would have existed there at the time of the MSC. This suggests that the Ergene fluvial network, possibly augmented with a catchment of the Maritsa River, could have been directed towards the Black Sea. Such a river could have been responsible for the incision of the Karamandere gorge and offshore valley and subsequent deposition of the large deltaic infill. This hypothesis with the palaeo-drainage network of the area is illustrated in Figures 13B (for peak of the MSC) and 13C (for post-MSC reflooding). In a similar scenario, Okay and Okay (2002) proposed that the palaeo-Maritsa-Ergene network flowed into the northern Marmara Sea domain prior to the Early Quaternary. We propose that, during the Late Miocene and Early Pliocene, the Maritsa-Ergene fluvial system was directed towards the Black Sea, but later progressively shifted to its present-day course as a result of the uplifting Strandja Sill (Sakınç et al., 1999; 
Sakınç and Yaltırak, 2005) and, probably, effect of the Mediterranean glacio-eustatic lowstands during the Quaternary (Fig. 13A).

\section{Conclusion}

The two sides of the Strandja Sill were investigated with the aim to specify its role in the possible connection between the Eastern Paratethys and Mediterranean during the period encompassing the MSC. Referring to the controversy about a proposed sea-level fall of the Black Sea before 7 Ma (Grothe et al., 2014), our re-visited dinoflagellate cyst records demonstrate that the Messinian Salinity Crisis significantly impacted the Black Sea, as expressed by a well-marked fluvial erosion. Our effort involved both new and existing observations and biostratigraphic age determinations in the onshore and offshore Black Sea areas in order to reconstruct the history of the sill during the whole Neogene, which is summarized in the synthesis displayed in Fig. 12. Only a connection at around 8 Ma may have existed, pointed out by Paratethyan molluscs which arrived on the Marmara side and dinoflagellate cysts which reached the Black Sea Site 380. At the time of the peak of the MSC, two opposite fluvial networks drained the region, which resulted in significant incisions. On the basis of these findings, we conclude that the Strandja Sill was not the gateway for the Paratethyan organisms that characterize any of the three Lago Mare events now well identified in the Mediterranean (Do Couto et al., 2014). The marine corridor evidenced in the Balkans (Clauzon et al., 2005; Popescu et al., 2009; Bache et al., 2012; Suc et al., this volume) was the appropriate gateway for late Messinian - early Zanclean water, which allowed crossed exchanges of Mediterranean and Eastern Paratethys organisms. The reconstructed erosion-sedimentation process of the southwestern Black Sea margin during the 
time-interval between 6 and 5 Ma constitutes a comprehensive model in an area intensively explored for hydrocarbons.

\section{Acknowledgements}

The onland investigations were realized during several field trips within the frame of the ANR EGEO Project. Seismic profiles were acquired during the BlaSON2 (Ifremer) survey on the R/V "Le Suroît". We particularly thank the reviewers of this manuscript: G. Tari for his constructive comments and an anonymous one who, in addition, made us benefiting from his appreciation of the field trip in Sept. 2013 and his knowledge of the DSDP Site 380.

\section{References}

Armijo, R., Meyer, B., Hubert, A., Barka, A., 1999. Westward propagation of the North Anatolian fault into the northern Aegean: Timing and kinematics. Geology 27(3), 267270.

Armijo, R., Meyer, B., Navarro, S., King, G., Barka, A., 2002. Asymmetric slip partitioning in the Sea of Marmara pull-apart: a clue to propagation processes of the North Anatolian Fault. Terra Nova 14(2), 80-86.

Bache, F., Popescu, S.-M., Rabineau, M., Gorini, C., Suc, J.-P., Clauzon, G., Olivet, J.-L., Rubino, J.-L., Melinte-Dobrinescu, M.C., Estrada, F., Londeix, L., Armijo, R., Meyer, B., Jolivet, L., Jouannic, G., Leroux, E., Aslanian, D., Dos Reis, A.T., Mocochain, L., Dumurdžanov, N., Zagorchev, I., Lesić, V., Tomić, D., Çağatay, M.N., Brun, J.-P., Sokoutis, D., Csato, I., Ucarkus, G., Çakir, Z., 2012. A two-step process for the 
reflooding of the Mediterranean after the Messinian Salinity Crisis. Bas. Res. 24, 125153.

Bartol, J., Govers, R., 2009. Flexure dur to the Messinian-Pontian sea level drop in the Black Sea. Geochem. Geophys. Geosystems 10, 10, Q10013, doi:10.1029/2009GC002672.

Çağatay, M.N., Görür, N., Flecker, R., Sakınç, M, Tünoğlu, C., Ellam, R., Krijgsman, W., Vincent,S., Dikbaş, A., 2006. Paratethyan - Mediterraenan connectivity in the Sea of Marmara region (NW Turkey) during the Messinian. Sedim. Geol. 188-189, 171-188.

Çağlayan, M.A., Yurtsever, A., 1998. 1/100,000 ölçekli Türkiye Jeoloji Haritaları 23, Kırklareli C6, MTA, Ankara, p. 99.

Chaput, E., Gillet, S., 1938. Les faunes de Mollusques des terrains à Hipparion gracile de Küçük Çekmece près Istanbul (Turquie). Bull. Soc. Géol. France Ser. 5, 8, 363-388.

Clauzon, G., Suc, J.-P., Popescu, S.-M., Mărunţeanu, M., Rubino, J.-L., Marinescu, F., Melinte, M.C., 2005. Influence of the Mediterranean sea-level changes over the Dacic Basin (Eastern Paratethys) in the Late Neogene. The Mediterranean Lago Mare facies deciphered. Bas. Res. 17, 437-462.

Do Couto, D., Popescu, S.-M., Suc, J.-P., Melinte-Dobrinescu, M.C., Barhoun, N., Gorini, C., Jolivet, L., Poort, J., Jouannic, G., Auxietre, J.-L., 2014. Lago Mare and the Messinian Salinity Crisis: Evidences from the Alboran Sea (S. Spain). Mar. Petrol. Geol. 52, 57-76. Duman, T.Y., Kecer, M., Ates, S., Emre, O., Gedik, I., Karakaya, F., Durmaz, S., Olgun, S., Sahin, H., Gokmenoglu, O., 2004. İstanbul Metropolu Batisindaki (Küçükcekmece - Silivri - Çatalca yöresi) Kentsel Gelisme Alanlarinin Yer Bilim Verileri. MTA Special Publication 3, p. 249 (in Turkish).

Georgiev, G., 2012. Geology and Hydrocarbon Systems in the Western Black Sea. Turkish J. Earth Sci., 21, 723-754. 
Geraads, D., Kaya, T. Mayda, S., 2005. Late Miocene large mammals from Yulafli, Thrace region, Turkey, and their biostratigraphic implications. Acta Palaeontol. Polonica 50, $523-544$.

Gillet, S., Gramann, F., Steffens, P., 1978. Neue biostratigraphische Ergebnisse aus dem brackischen Neogen an Dardanellen und Marmara-Meer (Türkei). Newslett. Stratigr. 7(1), 53-64.

Gillet, H., Lericolais, G., Rehault, J.-P., Dinu, C., 2003. La stratigraphie oligo-miocène et la surface d'érosion messinienne en mer Noire, stratigraphie sismique haute résolution. C. R. Geoscience 335, 907-916.

Gillet, H., Lericolais, G., Réhault, J.-P., 2007. Messinian event in the black sea: Evidence of a Messinian erosional surface. Mar. Geol. 244, 142-165.

Grothe, A., Sangiorgi, F., Mulders, Y.R., Vasiliev, I., Reichart, G.-J., Brinkhuis, H., Stoica, M., Krijgsman, W., 2014. Black Sea desiccation during the Messinian Salinity Crisis: Fact or fiction? Geology 42(7) 563-566.

Hsü, K.J., Giovanoli, F., 1979-1980. Messinian event in the Black Sea. Palaeogeogr., Palaeoclimatol., Palaeoecol. 29, 75-93.

Hugueney, M. 1999. Genera Eucricetodon and Pseudocricetodon. In: Rössner, G., Heissig, K. (Eds.), The Miocene Land Mammals of Europe, Friedrich Pfeil, Munich, 347-358.

Imren, C., Le Pichon, X. Rangin, C., Demirbağ, E. Ecevitoğlu, B., Görür, N., 2001. The North Anatolian Fault within the Sea of Marmara: a new interpretation based on multi-channel seismic and multi-beam bathymetry data. Earth Planet. Sci. Lett. 186, 143-158.

İslamoğlu, Y., Harzhauser, M., Gross, M., Jiménez-Moreno, G., Coric, S., Kroh, A., Rögl, F., van der Made, J., 2010. From Tethys to Eastern Paratethys: Oligocene depositional environments, paleoecology and paleobiogeography of the Thrace Basin (NW Turkey). Int. J. Earth Sci. 99, 183-200. 
Karakaş, Ç., 2012. Propagation et évolution structurale de la faille nord-anatolienne dans la région de Marmara (PhD Thesis). Univ. Diderot - Paris 7, p. 188.

Kaya, T., Heissig, K., 2001. Late Miocene Rhinocerotids (Mammalia) from Yulafli (ÇorluThrace/Turkey). Geobios 34(4), 457-467.

Krijgsman, W., Stoica, M., Vasiliev, I., Popov V.V., 2010. Rise and fall of the Paratethys Sea during the Messinian Salinity Crisis. Earth. Planet. Sci. Lett. 290, 183-191.

Le Pichon, X., Şengör, A.M.C., Demirbağ, E., Rangin, C., Imren, C., Armijo, R., Görür, N., Çağatay, N., de Lepinay, B.M., Meyer, B., Saatçılar, R., Tok, B., 2001. The active Main Marmara fault. Earth Planet. Sci. Lett. 192, 595-616.

Less, G., Özcan, E., Okay, A.I., 2011. Stratigraphy and Larger Foraminifera of the Middle Eocene to Lower Oligocene Shallow-Marine Units in the Northern and Eastern Parts of the Thrace Basin, NW Turkey. Turkish Journ. Earth Sci. 20, 793-845.

Letouzey, J., Gonnard, R., Montadert, L., Kristchev, K., Dorkel, A., 1978. Black Sea: geological setting and recent deposits distribution from seismic reflection data. In: Ross, D.A., Neprochnov, Y.P., et al. (Eds.), Initial Report of the Deep Sea Drilling Project, vol. 42(2), pp. 1077-1084.

Magyar, I., Geary, D.H., Sütő-Szentai, M., Lantos, M., Müller, P., 1999a. Integrated bio-, magneto- and chronostratigraphic correlations oft he late Miocene lake Pannon deposits. Acta Geol. Hung. 42, 5-31.

Magyar, I., Geary, D.H., Müller, P., 1999b. Paleogeographic evolution of the Late Miocene Lake Pannon in Central Europe. Palaeogeogr., Palaeoclimatol., Palaeoecol. 147, 151-167

Malik, A., Nafiz, H., 1933. Vertébrés fossiles de Küçük Çekmece, Istanbul. Comptes-Rendus somm. Soc. Géol. France, pp. 64-65.

Martini, E., Müller, C., 1986. Current tertiary and Quaternary calcareous nannoplankton stratigraphy and correlations. Newsl. Stratigr. 16(2), 99-112. 
Melinte-Dobrinescu, M.C., Suc, J.-P., Clauzon, G., Popescu, S.-M., Armijo, R., Meyer, B., Biltekin, D., Çağatay, M.N., Ucarkus, G., Jouannic, G., Fauquette, S., Çakir, Z., 2009. The Messinian Salinity Crisis in the Dardanelles region: Chronostratigraphic constraints. Palaeogeogr., Palaeoclimatol., Palaeoecol. 278, 24-39.

Murphy, L.N., Kirk-Davidoff, D.B., Mahowald, N., Otto-Bliesner, B.L., 2009. A numerical study of the climate response to lowered Mediterranean sea level during the Messinian Salinity Crisis. Palaeogeogr., Palaeoclimatol., Palaeoecol. 279, 41-59.

Nikishin, A.M., Petrov, E.I., 2014. Project “Geology Without Limits". New set of seismic data for Black Sea. Black Sea \& Caspian 2014 Conference, London, http://blackseandcaspian.com/presentations/6-Nikishin-Petrov.pdf.

Okay, N., Okay, A.I., 2002. Tectonically induced Quaternary drainage diversion in the northwestern Aegean. Journ. Geol. Soc. London 159, 393-399.

Okay, A.I., Özcan, E., 2014. Faulting, basement uplift and carbonate sedimentation: Çatalca region, West of İstanbul. Turkish Association of Petroleum Geologists, The Geological Field Guide Series, AAPG International Conference and Exhibition, İstanbul, PreConference field trip, $17 \mathrm{pp}$.

Okay, A.I., Şengör, A.M.C., Görür, N., 1999. Kinematic history of the opening of the Black sea and its effect on the surroundings regions. Geology 22, 267-270.

Okay, A.I., Tüysüz, O., 1999. Tethyan sutures of northern Turkey. In: Durand, B., Jolivet, L., Horváth, F., Séranne, M. (Eds.), The Mediterranean Basins: Tertiary Extension within the Alpine Orogen, Geol. Soc., London, Spec. Publ. 156, 475-515.

Orszag-Sperber, F., 2006. Changing perspectives in the concept of "Lago-Mare" in Mediterranean Late Miocene evolution. Sedim. Geol. 188-189, 259-277. 
Perch-Nielsen, K., 1985. Cenozoic calcareous nannofossils. In: Bolli, H.M., Saunders, J.B., Perch-Nielsen, K. (Eds.), Plankton Stratigraphy, Cambridge University Press, Cambridge, pp. $427-554$.

Perinçek, D., 1991. Possible Strand of the North Anatolian Fault in the Thrace Basin, TurleyAn Interpretation. Amer. Assoc. Petrol. Geol. Bull. 75(2), 241-257.

Popescu, S.-M., 2006. Late Miocene and early Pliocene environments in the southwestern Black sea region from high-resolution palynology of DSDP Site 380A (leg 42B). Palaeogeogr. Palaeoclimatol. Palaeoecol. 238, 64-77.

Popescu, S.-M., Biltekin, D., Winter, H., Suc, J.-P., Melinte-Dobrinescu, M.C., Klotz, S., Rabineau, M., Combourieu-Nebout, N., Clauzon, G., Deaconu F., 2010. Pliocene and Lower Pleistocene vegetation and climate changes at the European scale: Long pollen records and climatostratigraphy. Quat. Intern. 219, 152-167.

Popescu, S.-M., Dalesme, F., Jouannic, G., Escarguel, G., Head, M.J., Melinte-Dobrinescu, M.C., Sütő-Szentai, M., Bakrac, K., Clauzon, G., Suc, J.-P., 2009. Galeacysta etrusca complex, dinoflagellate cyst marker of Paratethyan influxes into the Mediterranean Sea before and after the peak of the Messinian Salinity Crisis. Palynology 33(2), 105-134.

Popov, S.V., Shcherban I.G., Ilyna, L.B., Nevesskaya, L.A., Paramonova, N.P., Khondkarian, S.O., Magyar, I., 2006. late Miocene to Pliocene palaeogeography of the paratethys and its relation to the Mediterranean. Palaeogeogr. Palaeoclimatol. Palaeoecol. 238, 91-106.

Okay, A.I., Şengör, A.M.C., Görür, N., 1994. Kinematic history of the opening of the Black Sea and its effect on the surrounding regions. Geology 22, 267-270.

Raffi, I., Backman, J., Fornaciari, E., Pälike, H., Rio, D., Lourens, L., Hilgen, F., 2006. A review of calcareous nannofossil astrobiochronology encompassing the past 25 million years. Quat. Sci. Rev. 25, 3113-3137. 
Raffi, I., Mozzato, C.A., Fornaciari, E., Hilgen, F.J., Rio, D., 2003. Late Miocene calcareous nannofossil biostratigraphy and astrobiochronology for the Mediterranean region. Micropaleontology 49, 1-26.

Rögl, F., 1999. Mediterranean and Paratethys. Facts and hypotheses of an Oligocene to Miocene paleogeography (short overview). Geol. Carpathica 50(4), 339-349.

Rögl, F., Steininger, F.F., 1983. Vom Zerfall der Tethys zu Mediterran und Paratethys. Die neogene Paläogeographie und Palinspastik des zirkum-mediterranen Raumes. Ann. Natirhist. Mus. Wien 85A, 135-163.

Ross, D.A., Yuri, P.P., Degens, E.T., Erickson, A.J., Hsü, K., Hunt, J.M., Manheim, F., Percival, S., Senalp, M., Stoffers, P., Supko, P., Traverse, A., Trimonis, E.A., 1978. Site 380. In: Ross, D.A., Neprochnov, Y.P., et al. (Eds.), Initial Report of the Deep Sea Drilling Project, vol. 42(2), pp. 120-291.

Ryan, W.B.F., S.M. Carbotte, J.O. Coplan, S. O'Hara, A. Melkonian, R. Arko, R.A. Weissel, V. Ferrini, A. Goodwillie, F. Nitsche, J. Bonczkowski, and R. Zemsky (2009), Global Multi-Resolution Topography synthesis, Geochem. Geophys. Geosyst. 10, Q03014, doi:10.1029/2008GC002332.

Sacleux, M., Nikishin, A., Munch, H., Floodpage, J., Cornu, T., 2013. Impact of the Messinian Crisis on petroleum systems. Amer. Ass. Petrol. Geol. European Regional Conference \& Exhibition, Barcelona, Abstract Book, 81.

Safak, U., Avsar, N., Meric, E., 1999. Bati Barkıkoy (İstanbul) Tersiyer cokellerinin ostrakod ve foraminifer toplulugu. MTA Journ. 121, 17-31 (in Turkish).

Sakınç, M., Yaltırak, C., 2005. Messinian crisis: What happened around the northeastern Aegean? Mar. Geol. 221, 423-436. 
Sakınç, M., Yaltırak, C., Oktay, F.Y., 1999. Palaeogeographical evolution of the Thrace Neogene Basin and the Tethys-Paratethys relations at northwestern Turkey (Thrace). Palaeogeogr., Palaeoclimatol., Palaeoecol. 153, 17-40.

Schrader, H.-J., 1978. Quaternary through Neogene history of the Black Sea, deduced from the paleoecology of diatoms, silicoflagellates, ebridians, and chrysomonads. In: Ross, D.A., Neprochnov, Y.P., et al. (Eds.), Leg 42B. Initial Reports of the Deep Sea Drilling Project, vol. 42(2), pp. 789-902.

Şengör, A. M. C., Grall, C., İmren, C., Le Pichon, X., Görür, N., Henry, P., Karabulut, H., and Siyako, M., 2014, The geometry of the North Anatolian transform fault in the Sea of Marmara and its temporal evolution: implications for the development of intracontinental transform faults. Canadian J. Earth Sci. 51(3), 222-242.

Şengör, A.M.C., Tüysüz, O., İmren, C., Sakınç, M., Eyidoğan, H., Görür, N., Le Pichon, X., Rangin, C., 2005. The North Anatolian Fault: a new look. Annu. Rev. Earth Planet. Sci. $33,37-112$.

Stoffers, P., Müller, G., 1979. Carbonate rocks in the Black Sea Basin: Indicators for shallow water and subaerial exposure during Miocene-Pliocene time. Sedim. Geol. 23, 137-147.

Suc, J.-P., Clauzon, G., Armijo, R., Meyer, B., Melinte-Dobrinescu, M.C., Popescu, S.-M., Lericolais, G., Gillet, H., Çağatay, M.N., Jouannic, G., Brun, J.-P., Sokoutis, D., Ucarkus, G., Çakir, Z., 2009. The Messinian Salinity Crisis in the Northeastern Aegean - Black Sea region. 13th RCMNS Congress Naples, Acta Naturalia de L'Ateneo Parmense, 45(1/4), pp. 116-117.

Suc, J.-P., Do Couto, D., Melinte-Dobrinescu, M.C., Macaleţ, R., Quillévéré, F., Clauzon, G., Csato, I., Rubino, J.-L., Popescu, S.-M., 2011. The Messinian Salinity Crisis in the Dacic Basin (SW Romania) and early Zanclean Mediterranean - Paratethys high sea-level connection. Palaeogeogr., Palaeoclimatol., Palaeoecol. 310, 256-272. 
Suc, J.-P., Popescu, S.-M., Do Couto, D., Clauzon, G., Rubino, J.-L., Melinte-Dobrinescu, M.C., Quillévéré, F., Brun, J.-P., Dumurdžanov, N., Zagorchev, I., Lesdić, V., Tomić, D., Sokoutis, D., Meyer, B., Macaleţ, R., Jelen, B., Rihelj, H., submitted. Marine gateway vs. fluvial stream within the Balkans from 6 to 5 Ma. Mar. Petrol. Geol. this volume.

Tari, G., Dellmour, J.D.R., Larratt, E., Novotny, B., Kozhuharov, E., 2009. Play types and hydrocarbon potential of the deepwater Black Sea, NE Bulgaria. The Leading Edge 28, $1076-1081$.

Tari, G., Fallah, M., Walter, K., 2013. The signature of the Mediterranean Messinian Salinity Crisis in the Black Sea and Caspian Basins: A Comparison. Amer. Ass. Petrol. Geol. European Regional Conference \& Exhibition, Barcelona, Abstract Book, 80.

Tari, G., Kosi, W., Fallah, M., Schell, C., Bretis, B., submitted. Is the impact of the Messinian Salinity Crisis in the Black Sea comparable to that of the Mediterranean? Mar. Petrol. Geol. this volume.

Ternek, Z., 1964. 1/500,000 ölçekli Türkiye Jeoloji Haritası, İstanbul. Harita genel Müdürlüğü Matbaasında basılmıştır, Ankara.

Türkecan, A., Yurtsever, A., 2002. 1/500.000 scale geological maps of Turkey, İstanbul. MTA, Ankara.

Ünay, E., Atabey, E., Saraç, G. 2001. Small mammals and Foraminifera from the Anatolian (Central Taurus) Early Miocene. Ann. Carnegie Mus. 70, 247-256.

Vasiliev, I., Iosifidi, A.G., Khramov, A.N., Krijgsman, W., Kuiper, K., Langereis, C.G., Popov, V.V., Stoica, M., Tomsha, V.A., Yudin, S.V., 2011. Magnetostratigraphy and radio-isotope dating of upper Miocene-lower Pliocene sedimentary succession of the Black sea Basin (Taman Peninsula, Russia). Palaeogeogr., Palaeoclimatol., Palaeoecol. $310,163-175$. 
Vasiliev, I., Reichart, G.-J., Krijgsman, W., 2013. Impact oft he Messinian Salinity Crisis on Black Sea hydrology-Insights from hydrogen isotopes analysis on biomarkers. Earth Planet. Sci. Lett., 362, 272-282.

Yaltırak, C., Sakınç, M., Oktay, F.Y., 1999. Westward propagation of North Anatolian fault into the northern Aegean: Timing and kinematics. Geology 28(2), 187-188.

Young, J.R., 1998. Chapter 9: Neogene. In: Brown P.R. (Ed.), Calcareous Nannofossils Biostratigraphy, British Micropaleontological Society Publications Series, Kluwer Academic Press, Dordrecht, pp. 225-265.

Yurtsever, A., Çağlayan, M.A., 2002. 1/100,000 ölçekli Türkiye Jeoloji Haritaları 65, İstanbul F21, MTA, Ankara, p. 30.

\section{Figure Captions}

Fig. 1. Location maps.

A, Location of the study area.

Palaeogeography of the Central and Eastern Paratethys at the latest Miocene is from Krijgsman et al. (2010).

B, Simplified geological map of the Strandja Sill area (from: Çağlayan and Yurtsever, 1998; Yurtsever and Çağlayan, 2002; Türkecan and Yurtsever, 2002) with the Black Sea offshore wells and location of the BlaSON seismic profiles presented in this paper. $a-b$, Geological section through the Strandja Sill shown in Figure 2;

Localities: 1, Beykent; 2, Avcılar; 3, Kayabaşı; 4, Akpınar; 5, Kocayemiş. 
WBSF, West Black Sea Fault; TEFZ, Thrace-Eskişehir Fault Zone.

The green box corresponds to the geological map of the Karacaköy area shown in Figure 6A.

Fig. 2. Cross-section $\mathrm{a}-\mathrm{b}$ through the Strandja Sill according to the geological map of Yurtsever and Çağlayan (2002).

Fig. 3. The Beykent section.
A, General view.
B, Lithology and formations.
C, Detail of pebbles.
D, Clayey lens within the pebbles.
E, Zoom on the Çukurçeşme and Bakırköy formations.

Fig. 4. The Avcrlar section. 1 to 6 , samples.
A, Lower part of the section.
B, Upper part of the section.

Fig. 5. The Akpınar quarry.
A, General view of the section.
B, Zoom on the base of the section with location of samples 1 and 2 .
C, Zoom on the top of the section with location of samples 3 and 4.

Fig. 6. The Karacaköy area.

A, Simplified geological map at scale 1/100,000 from Çağlayan \& Yurtsever (1998). 
1, Exposed surface section from the Thrace Basin; 2, Exposed section in the descent to the North of the Karamandere pass; 3, Quarry westward of Karacaköy; 4, Quarry between Karacaköy and Ormanlı.

$\mathrm{B}$, Section observed at site 1 showing a quartzite seam crossing the Ergene Formation at the topmost of the Thrace Basin;

C, Cross-bedded fluvial sands of the Ergene Formation at site 2;

D, Sands and gravels of the Ergene Formation worked in the quarry of site 3;

E, Sands and gravels of the Ergene Formation worked in the quarry of site 4;

F, Silicified tree trunks from the Ergene Formation at site 4.

Fig. 7. Geology of the northern side of the Karamandere pass.
A, East-West panoramic photograph (with location of photograph of Figure B).
B, View showing deposits of the Ergene Formation nested within the basement rocks at the Karamandere pass.
C, Interpreted geology and geomorphology of the panoramic view, with respect to the geological map of Çağlayan \& Yurtsever (1998).

Fig. 8. Dinoflagellate cyst content from the interval 840.07 - 1019.85 m of DSDP Site 380 .

Fig. 9. Seismic profile BlaSON2-054.
A, Non interpreted profile.
$\mathrm{B}$, Interpreted profile.

Fig. 10. Seismic profile BlaSON2-052.

A, Non interpreted profile with location of the Karadeniz 1 well. 
B, Interpreted profile with stratigraphic subdivision of the Karadeniz 1 well.

Fig. 11. Seismic profile BlaSON2-051.
A, Non interpreted profile with location of the projected İğneada 1 well.
B, Interpreted profile with stratigraphic subdivision of the projected İğneada 1 well.

Fig. 12. Interpreted onland stratigraphic successions on both sides of the Strandja Sill. Reference to the Paratethys Stratigraphy is done for the time interval corresponding to its more or less continuous isolation, i.e. from the early Sarmatian s.l. (= midSerravallian) to Kimmerian (= Zanclean).

M, Mammals; N, Calcareous nannofossils; Mo, Molluscs; D, Dinoflagellate cysts.

Double arrow: possible marine connection.

Hatched areas: sedimentary gaps.

Fig. 13. Reconstructed geography and fluvial network of the Strandja Sill region at the end of Messinian and beginning of Zanclean with comparison to the present-day hydrography of the region.
A, Present-day main rivers. The map was created using the GeoMapApp@System http://www.geomapapp.org/ (Ryan et al., 2009).
B, Palaeogeography during the peak of the Messinian Salinity Crisis (5.5 Ma).
C, Palaeogeography after the marine reflooding (5.31 Ma).

Plate 1. Dinoflagellate cysts of the Galeacysta etrusca Complex recorded in the Aragonite and Black shales units of Site 380 compared to reference specimens.

Bar scale: $20 \mu \mathrm{m}$. 
Fig. 1. Galeacysta etrusca, reference specimen from Krajačići at the scanning electronic microscope (latest Tortonian, Pannonian Basin; Popescu et al., 2009). Figs. 2a, 2b. Galeacysta etrusca, Site 380 (1009.36 m) in fluorescence microscopy. Fig. 3. Romanodinium areolatum, reference specimen from Majs 2 at the scanning electronic microscope (late Tortonian, Pannonian Basin; Popescu et al., 2009). Figs. 4a, 4b. Romanodinium areolatum, Site $380(1009.36 \mathrm{~m})$ in fluorescence microscopy.

Fig. 5. Spiniferites balcanicus, reference specimen from Hinova at the scanning electronic microscope (latest Messinian, Dacic Basin; Popescu et al., 2009).

Figs. 6a, 6b. Spiniferites balcanicus, Site 380 (846.14 m) in fluorescence microscopy. 


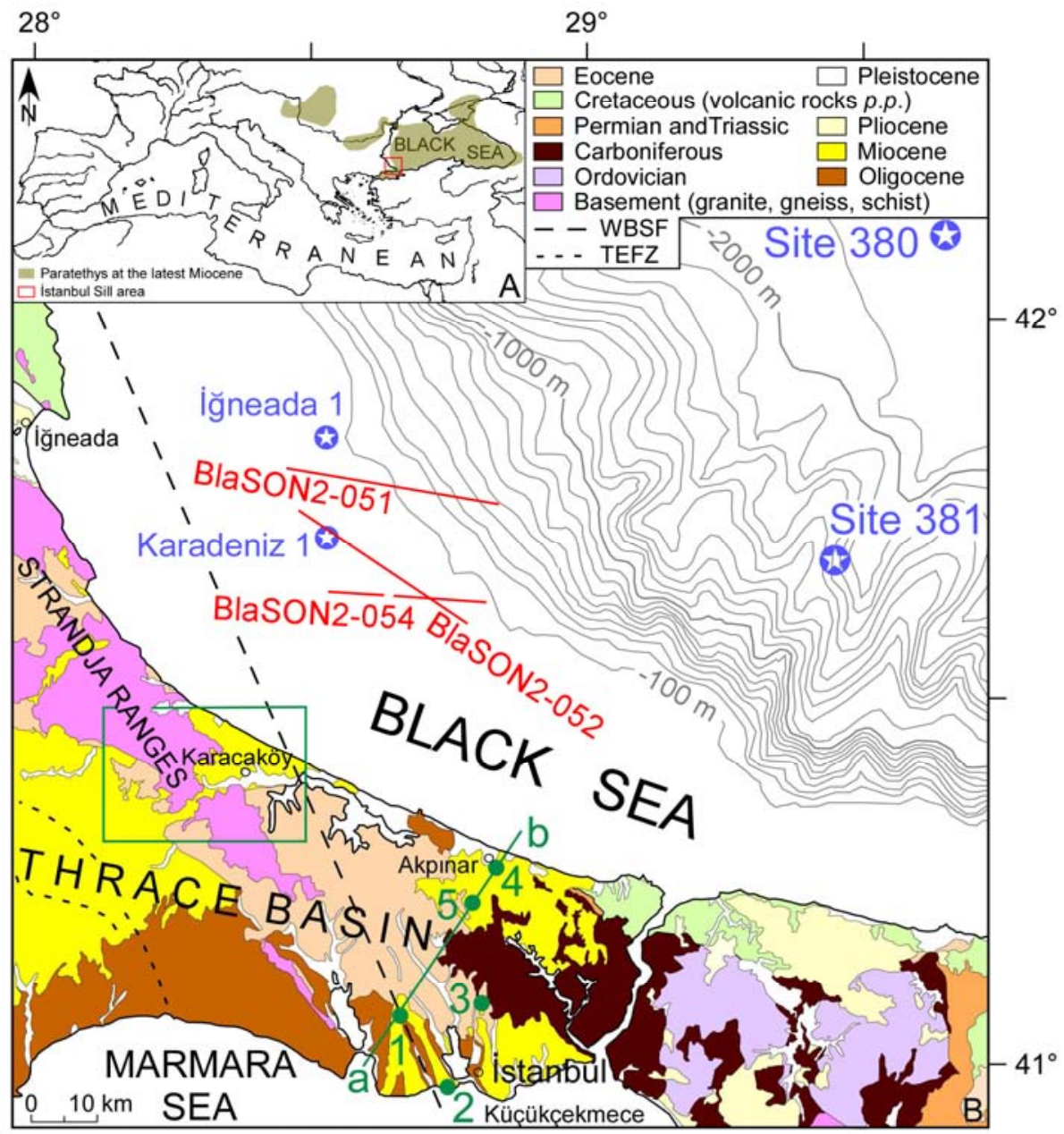




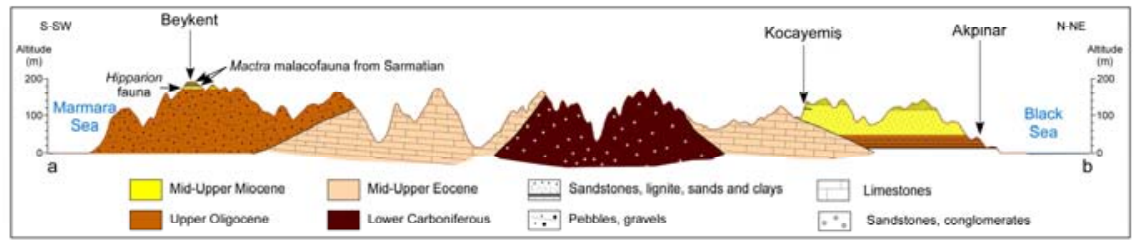




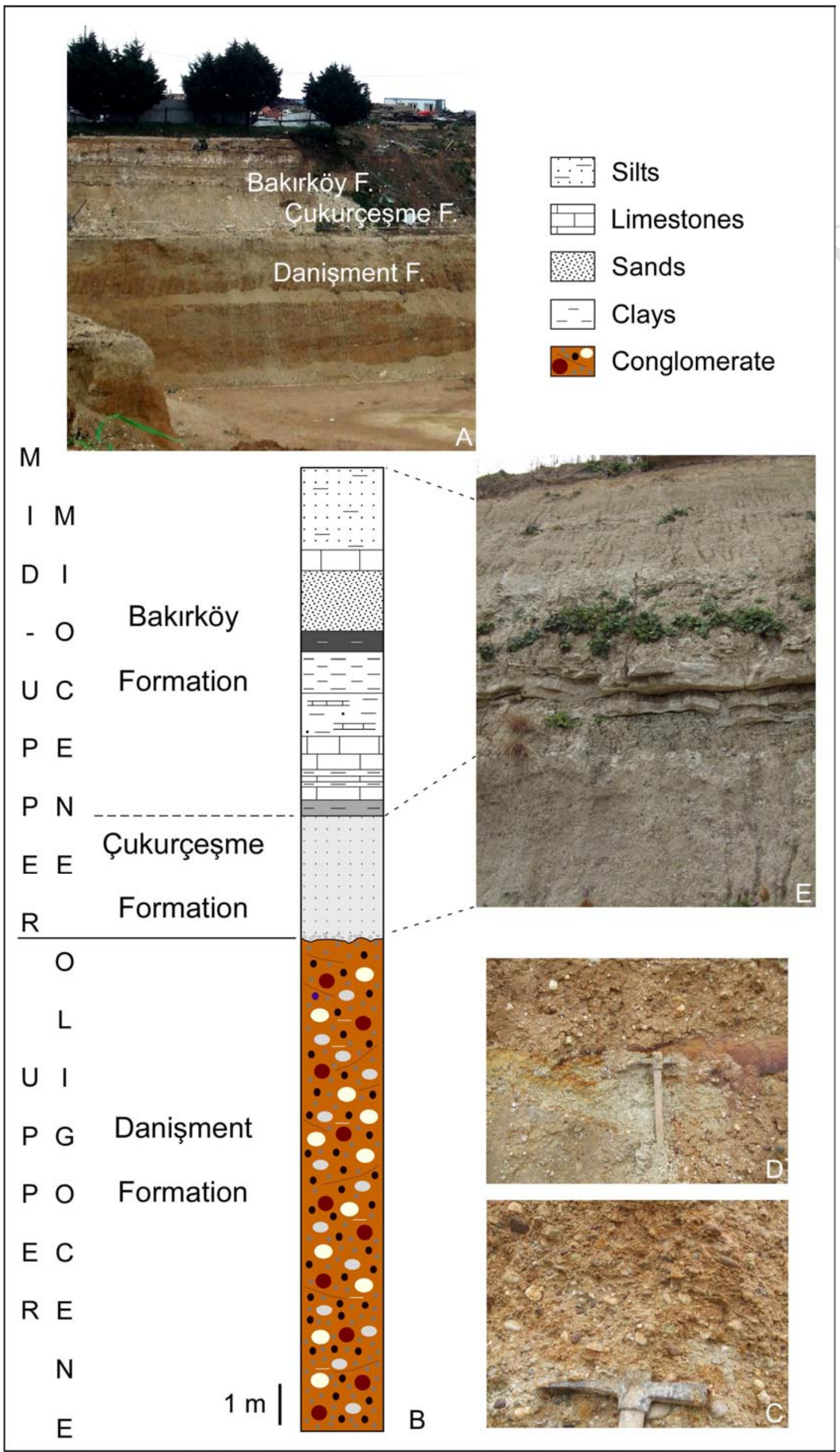




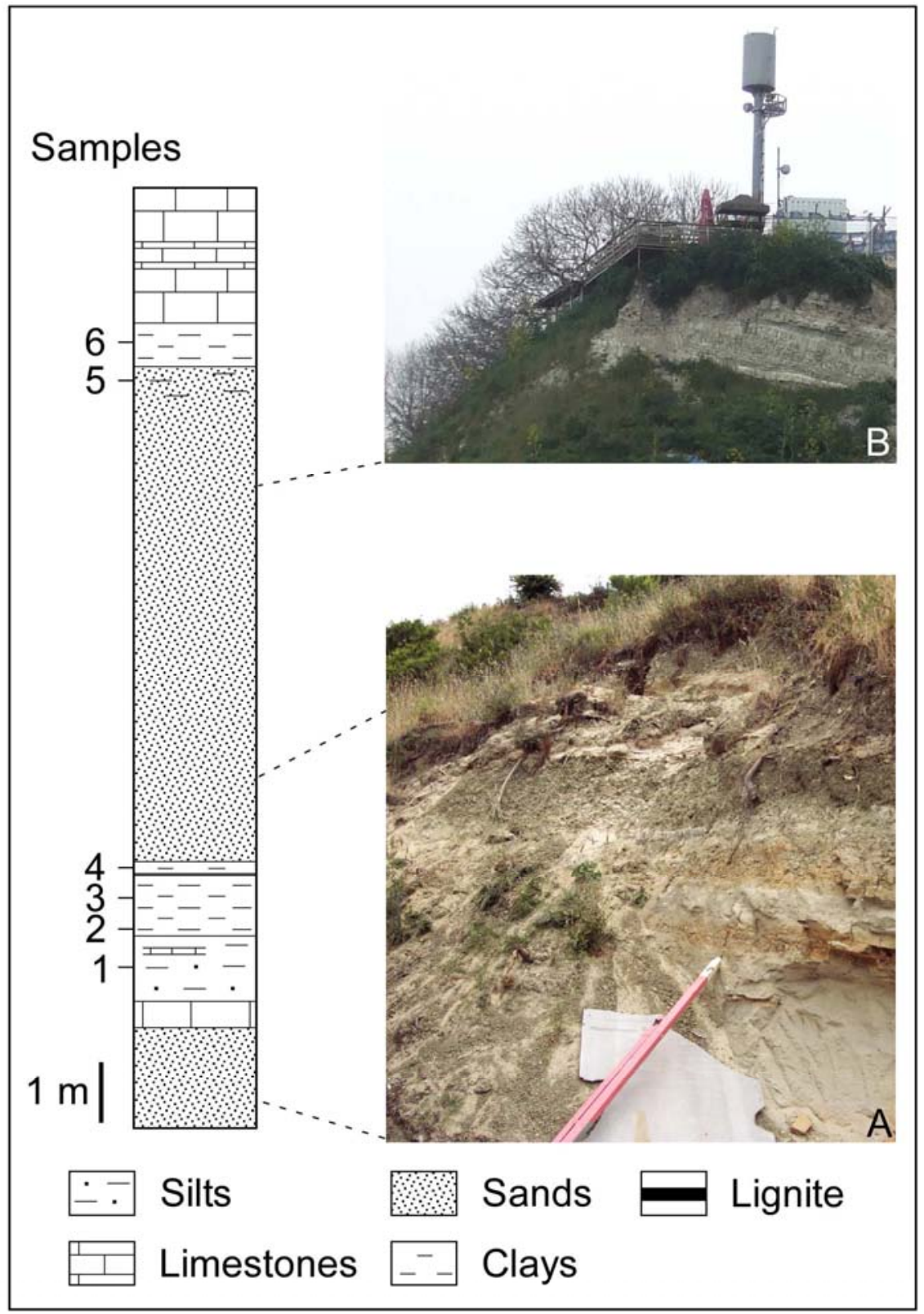




\section{ACCEPTED MANUSCRIPT}
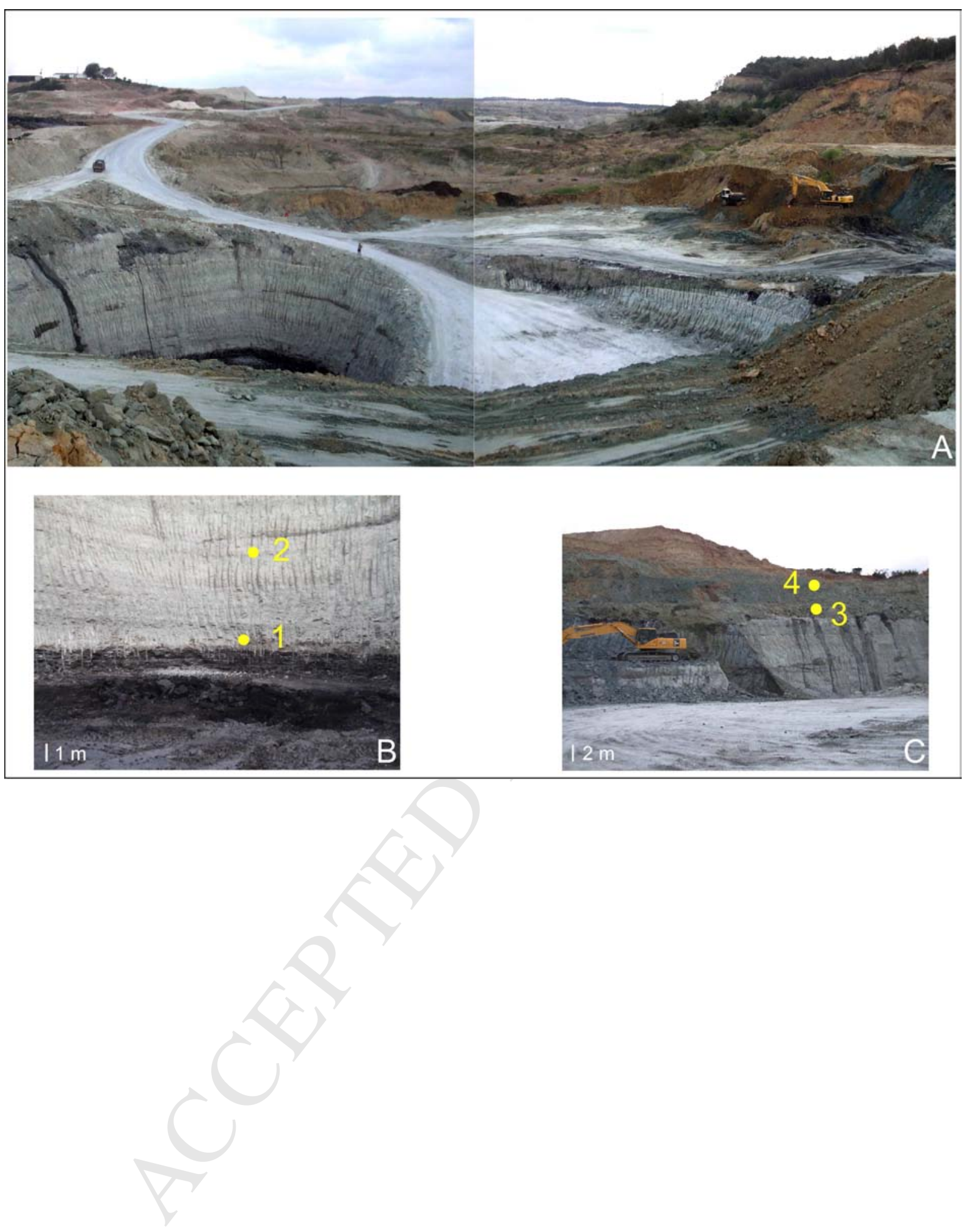

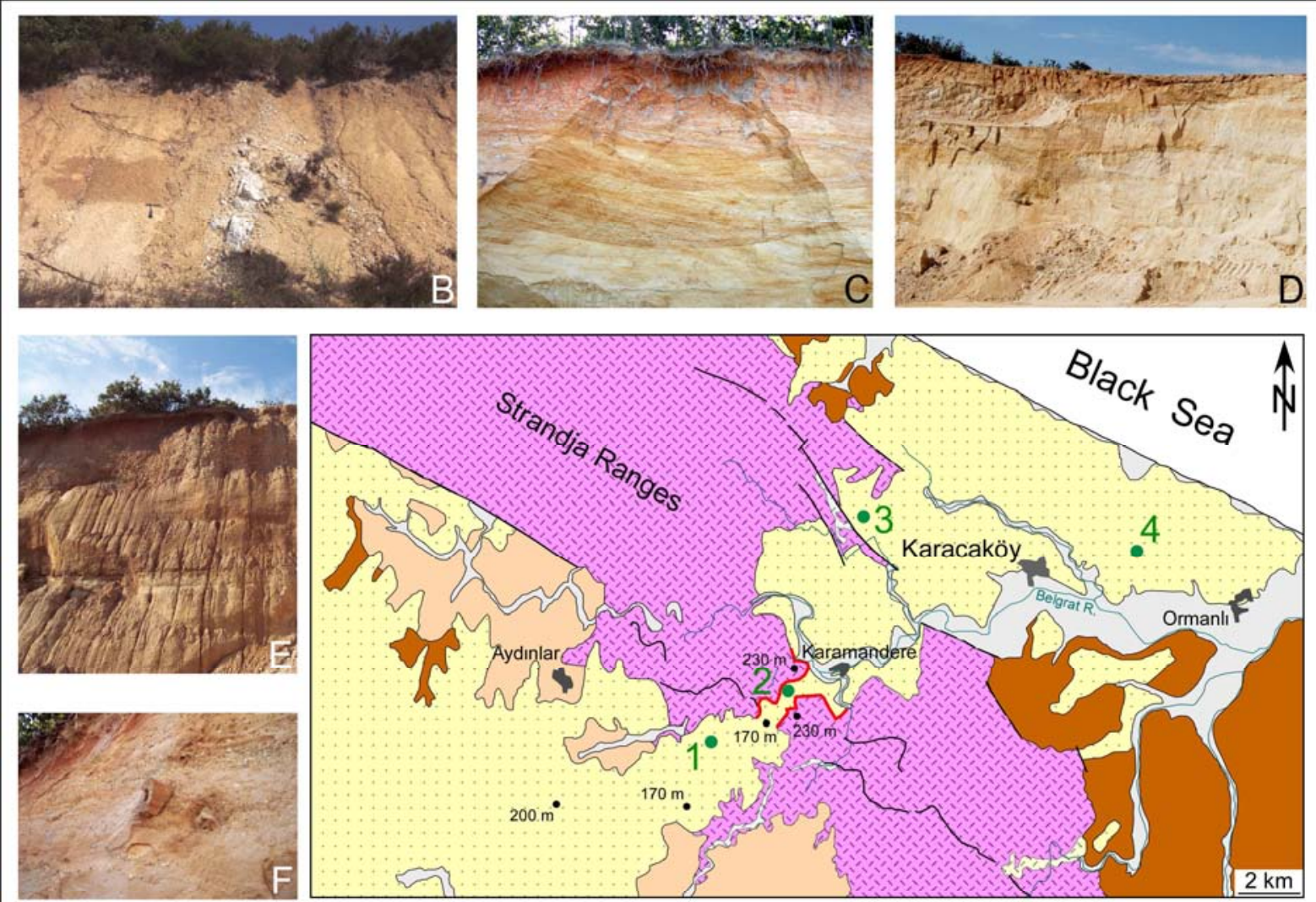

Ergene Formation: sands (Upper Miocene - Pliocene)

Holocene $\smile$ Erosional surface

Basement (granite, schists, quartzites)

Eocene $\square$ Oligocene

A 


\section{ACCEPTED MANUSCRIPT}
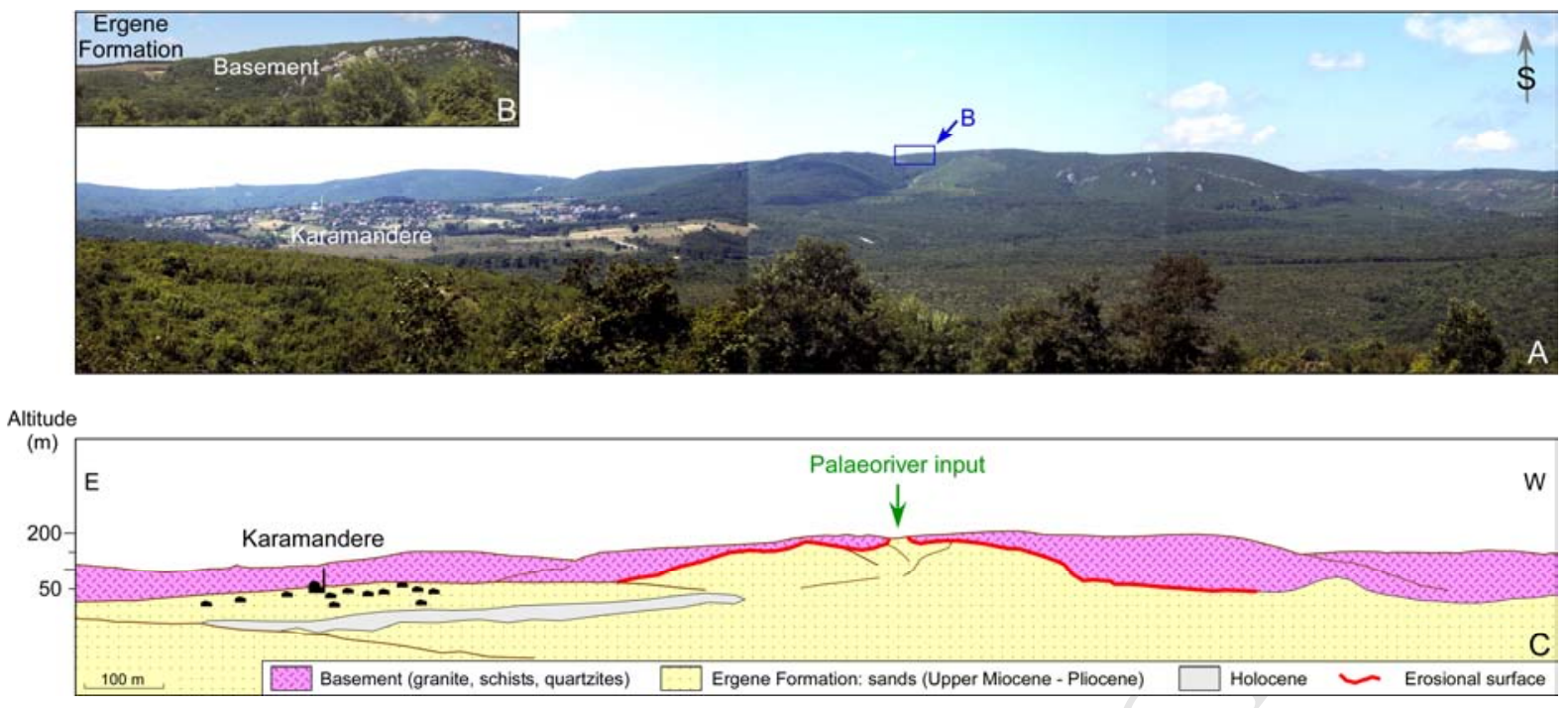


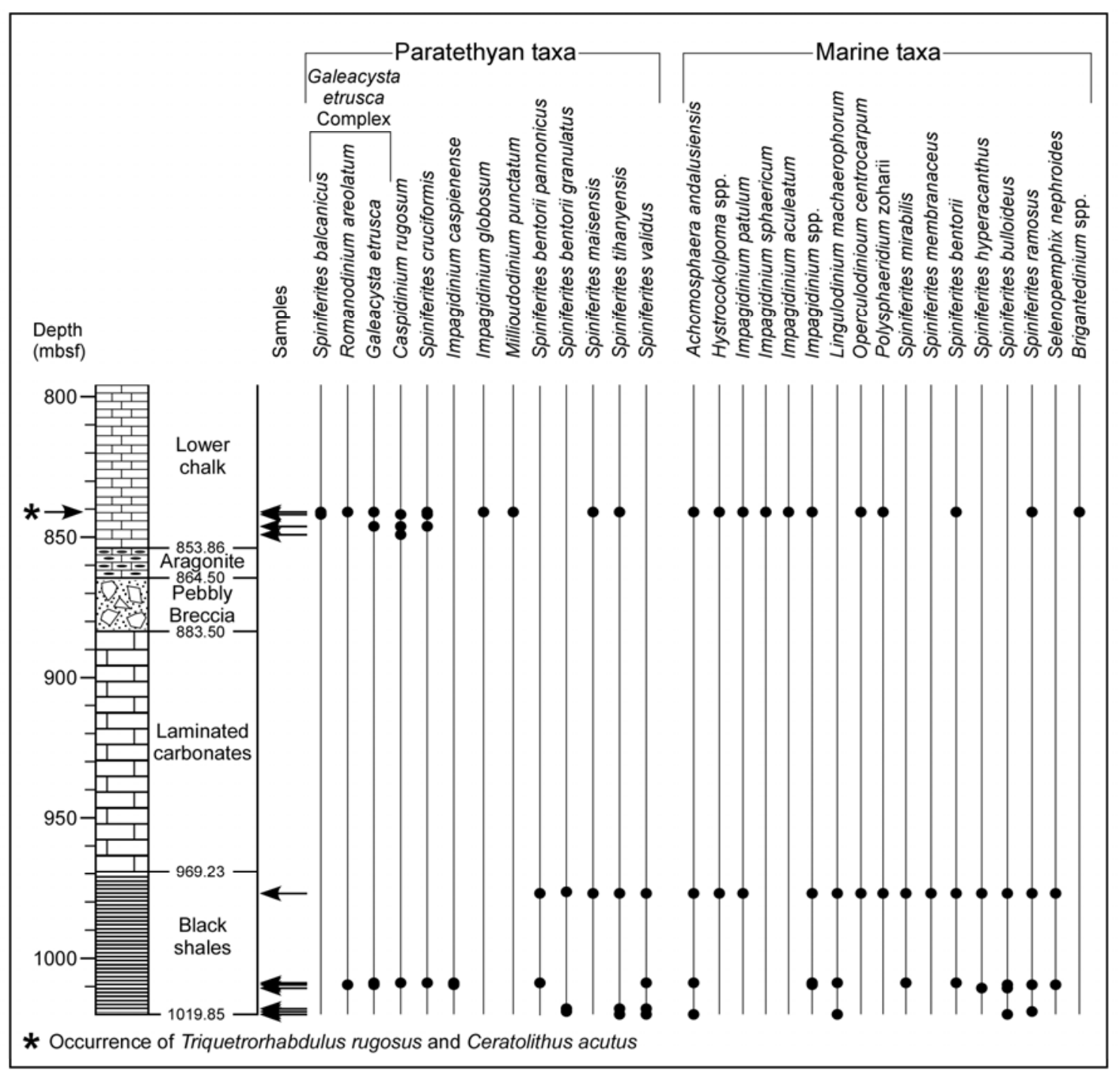




\section{ACCEPTED MANUSCRIPT}

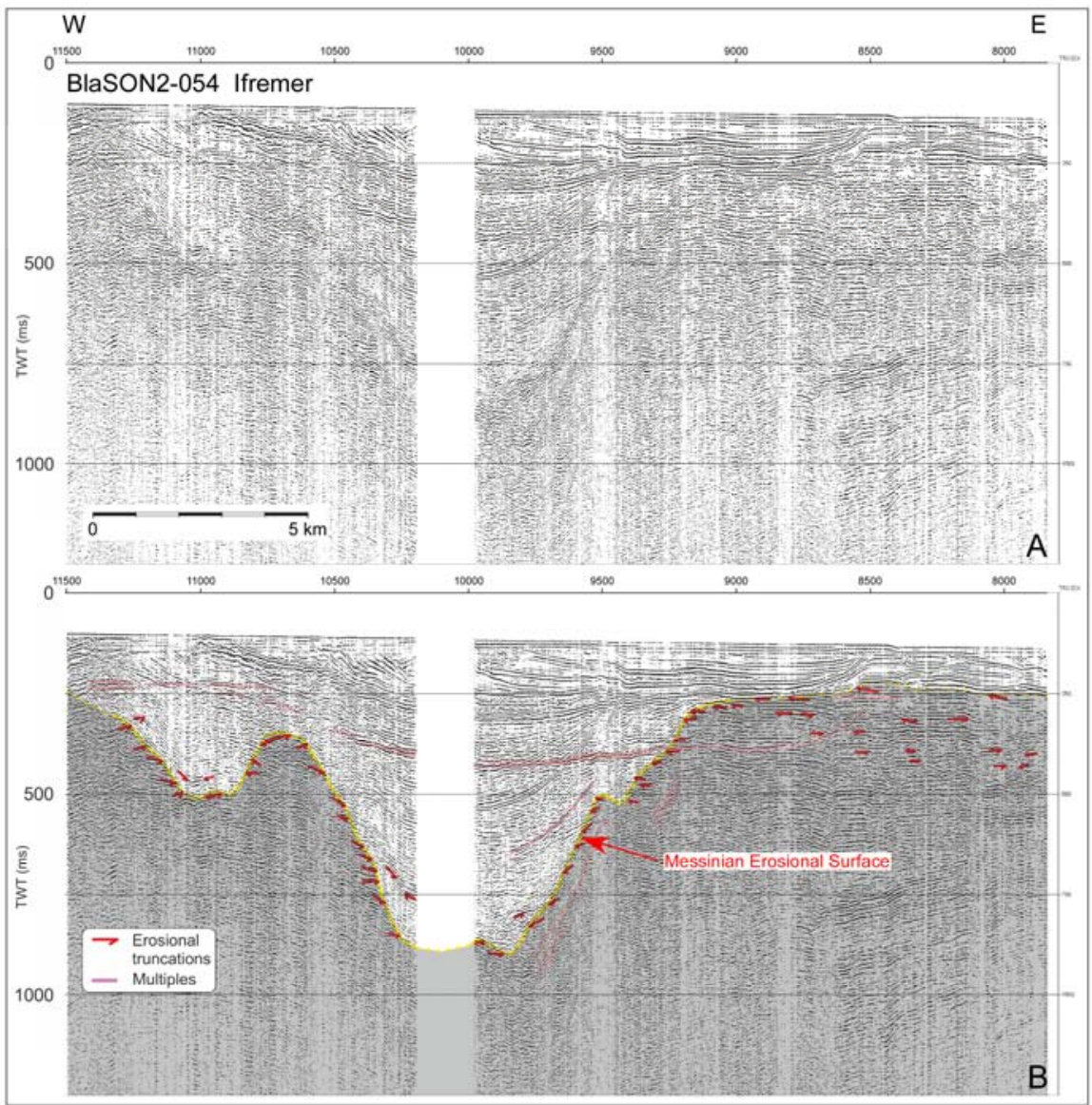




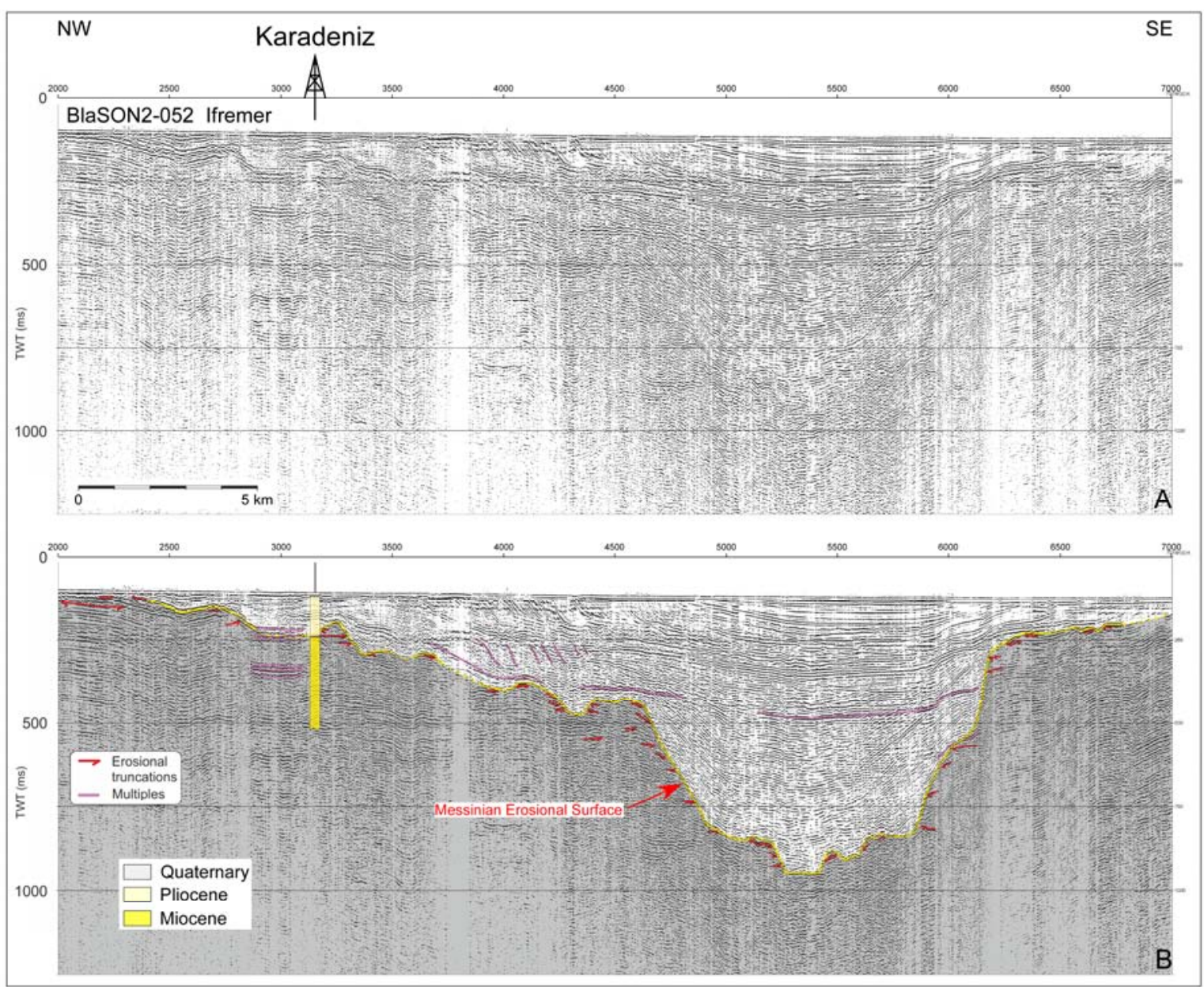




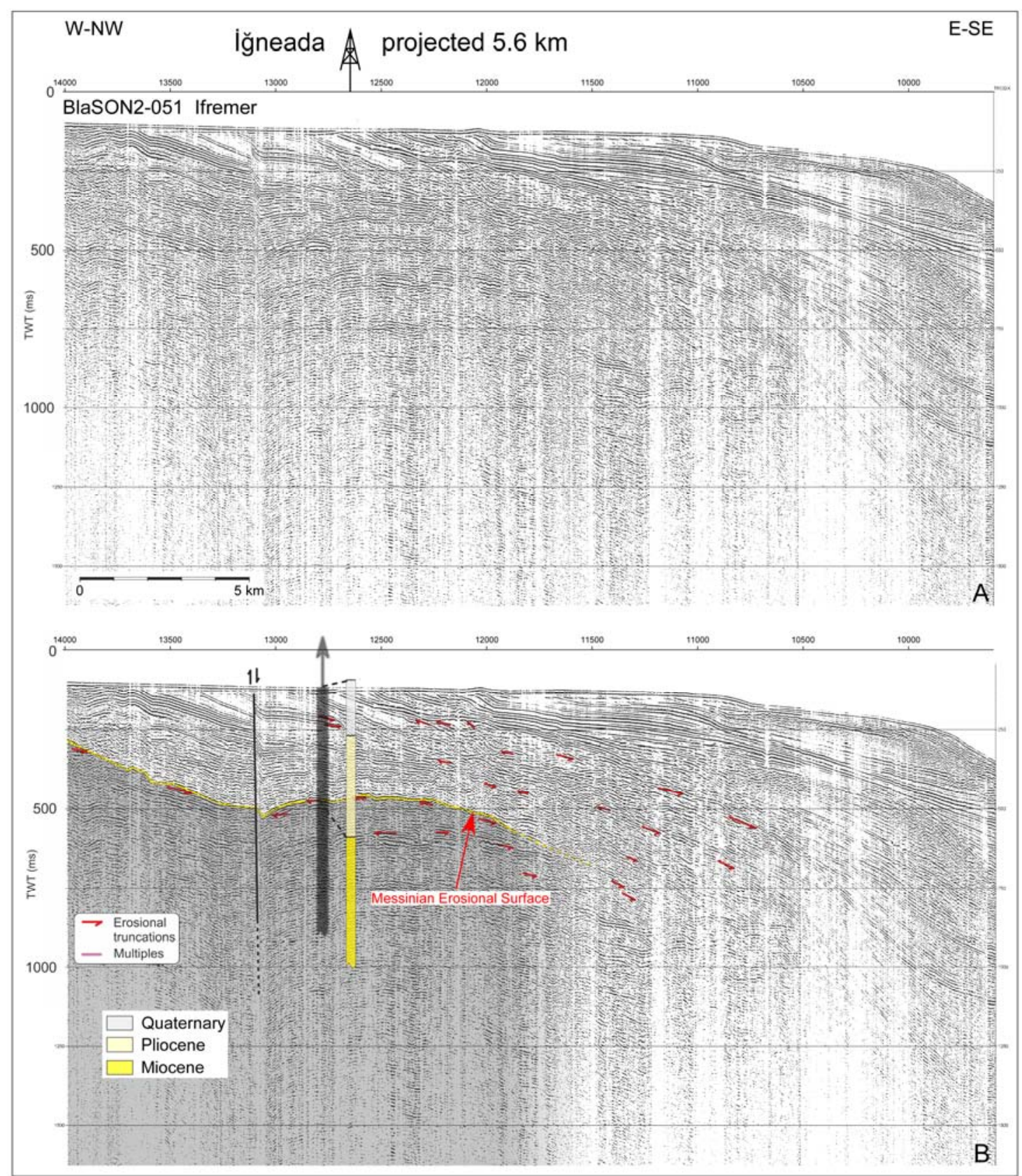


ACCEPTED MANUSCRIPT

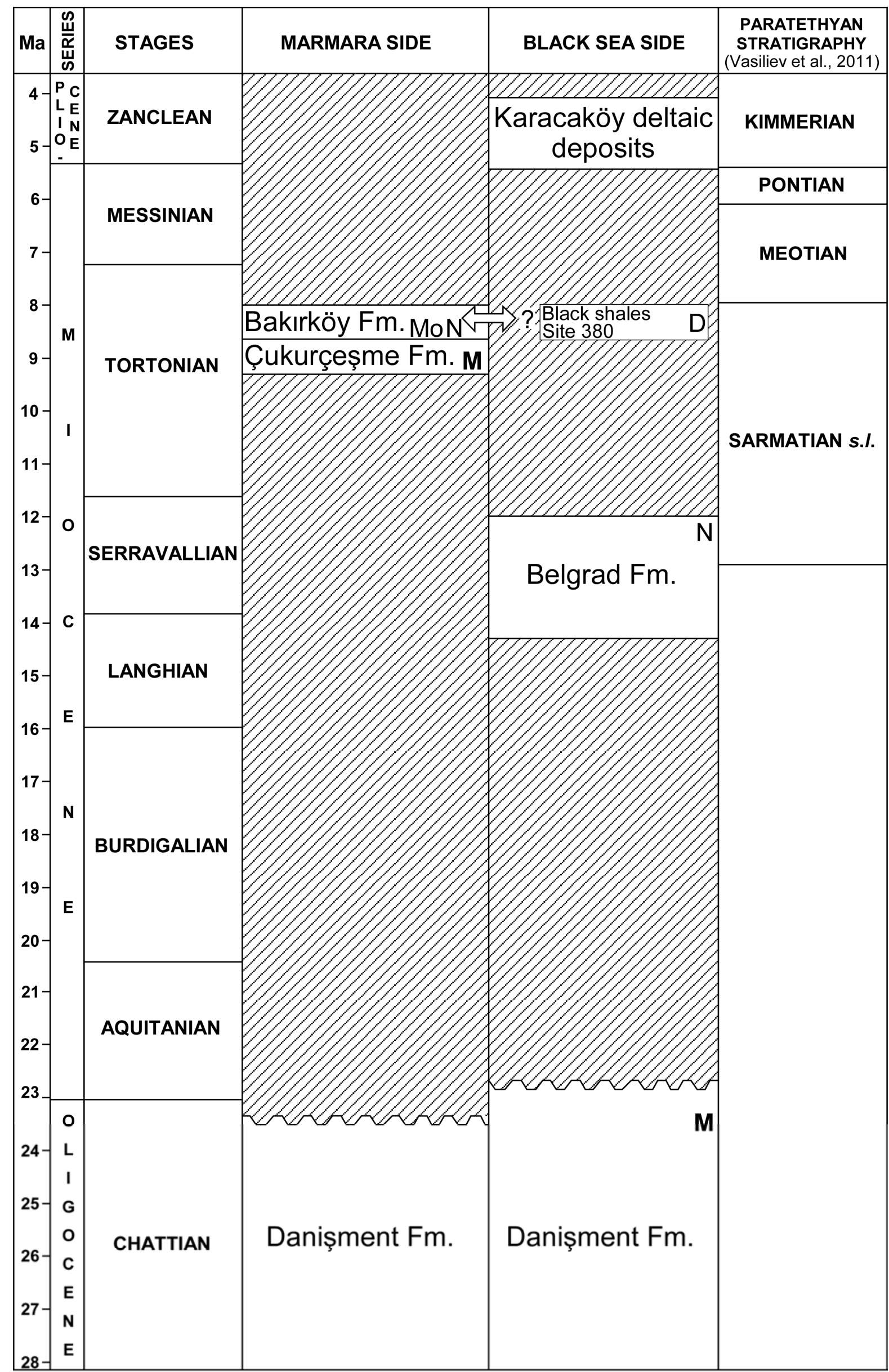



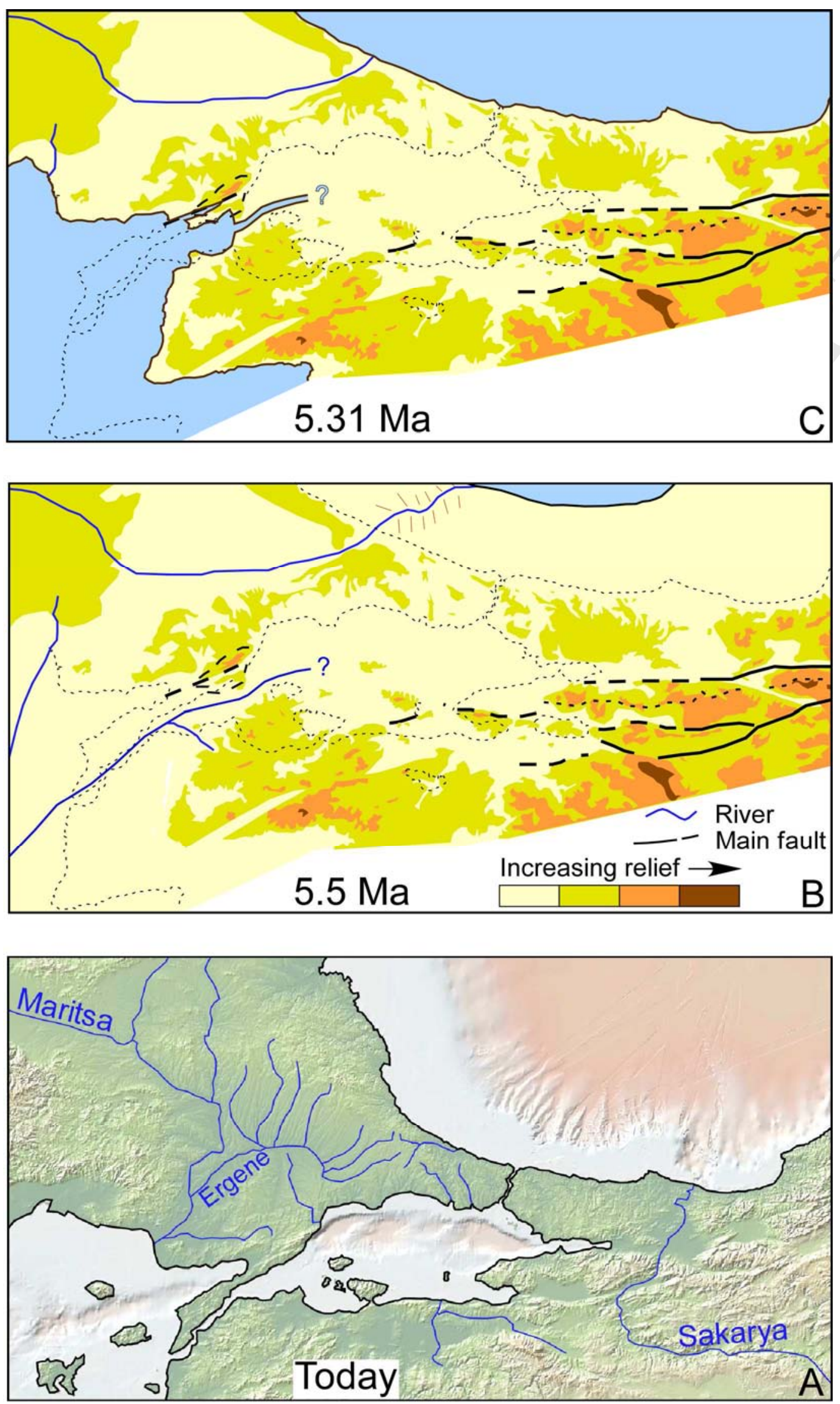

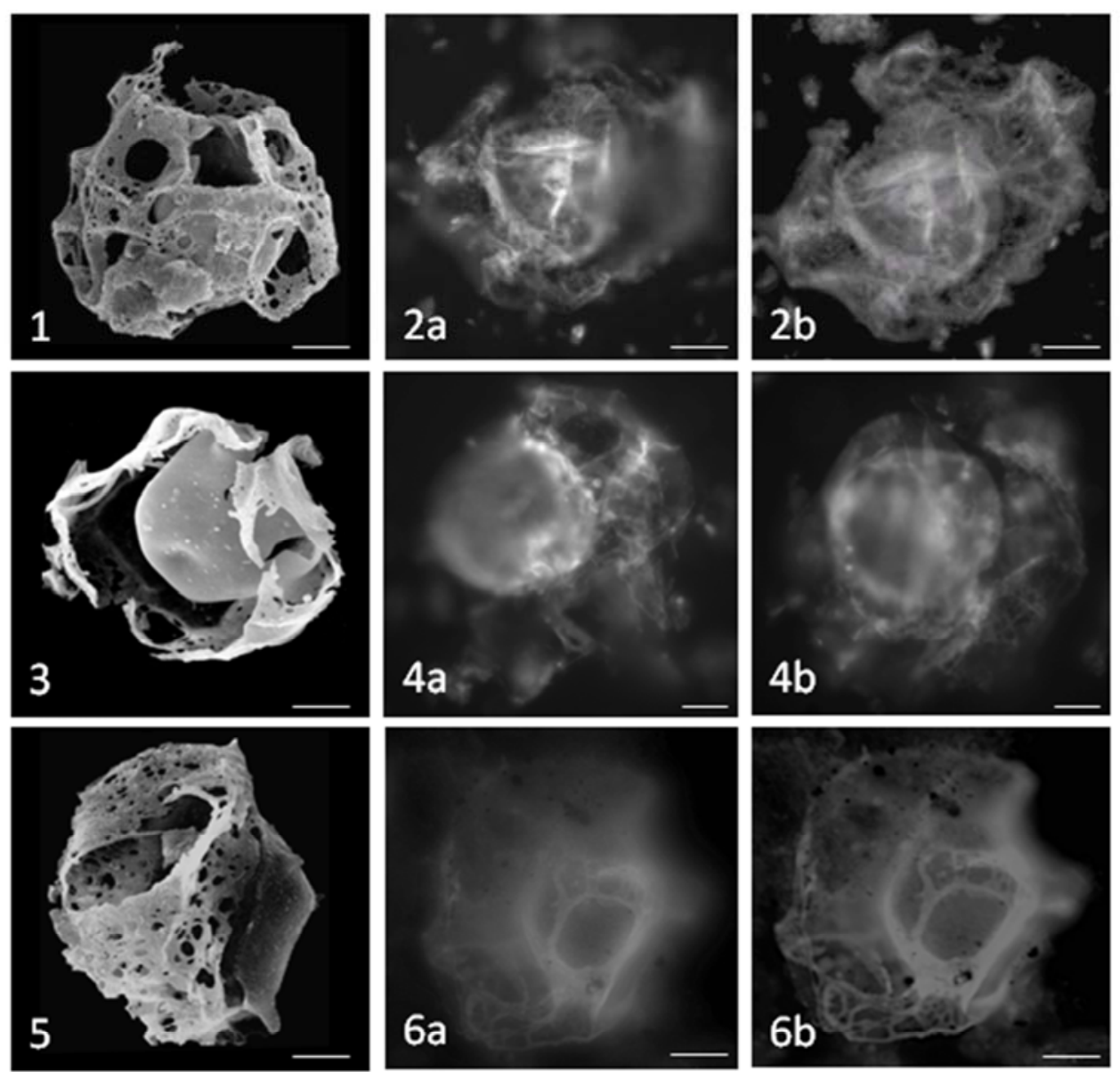